
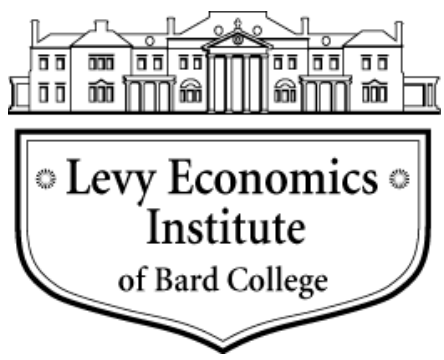

Working Paper No. 983

\title{
Intrahousehold Allocation of Household Production: A Comparative Analysis for Sub-Saharan African Countries
}

by

\author{
Fernando Rios-Avila* \\ Levy Institute \\ Abena D. Oduro \\ University of Ghana \\ and \\ Luiza Nassif-Pires \\ Levy Institute
}

February 2021

\begin{abstract}
* We are grateful to the William and Flora Hewlett Foundation for their generous financial support for the Levy research project on intrahousehold disparities in household production, as a part of which, this paper was written. We are also grateful to our colleagues Ajit Zacharias and Thomas Masterson for their helpful comments. We are also grateful to Alemayehu Teferi and Asalfew Abera of the Central Statistical Agency (Ethiopia) for their help with obtaining the time-use survey data.

The Levy Economics Institute Working Paper Collection presents research in progress by Levy Institute scholars and conference participants. The purpose of the series is to disseminate ideas to and elicit comments from academics and professionals.
\end{abstract}

Levy Economics Institute of Bard College, founded in 1986, is a nonprofit, nonpartisan, independently funded research organization devoted to public service. Through scholarship and economic research it generates viable, effective public policy responses to important economic problems that profoundly affect the quality of life in the United States and abroad.

Levy Economics Institute

P.O. Box 5000

Annandale-on-Hudson, NY 12504-5000

http://www.levyinstitute.org

Copyright (C) Levy Economics Institute 2021 All rights reserved

ISSN 1547-366X 


\begin{abstract}
In this working paper, we analyze factors that may explain gender differences in the allocation of time to household production in sub-Saharan Africa. The study uses time use survey data to analyze the determinants of time spent on household production by husbands and wives in nuclear families in Ethiopia, Ghana, Tanzania, and South Africa. We assume that the time spent by each spouse is a function of personal and household characteristics. A bivariate Tobit model is used to estimate the marginal impact of a set of key variables that figure recurrently in the literature on time allocation. We observe a high degree of variability in the results for the set of countries, which does not allow us to draw hard general conclusions. We do find some weak evidence that supports time availability and gender ideology theory as well as for the hypothesis that bargaining power plays a role in explaining the intrahousehold allocation of household production.
\end{abstract}

KEYWORDS: Time Use; Household Production; Economics of the Family; Gender

JEL CLASSIFICATIONS: D13; D61; J22; C34 


\section{INTRODUCTION}

As in many regions across the globe, women across sub-Saharan Africa are the primary persons responsible for performing unpaid household work, such as cooking, cleaning, and caring for children, the elderly, and the sick. Even women that actively work for pay take up the largest share of responsibilities of household production, increasing their risk of falling into what has been termed "time poverty" (Zacharias et al. 2018). In contrast, men are far less involved in these activities. Not only do they seem to engage fewer hours of their time in household production, but they are also less likely to do household chores at all (Zacharias et al. 2018).

The gender gap in the distribution of unpaid household work can have increasingly negative effects on women's welfare. In addition to their increased likelihood of falling into time poverty, the unequal distribution of household responsibilities may contribute to the gender wage gap by reducing women's participation in paid work or pushing them toward part-time work and the informal sector.

The gendered and unequal distribution of household work is a topic of current concern. Reducing women's burden domestic work and childcare burden through the "promotion of shared responsibility within the household and the family"1 is one of the targets of goal five of the United Nation's Sustainable Development Goal (SDGs). To design effective policies to reduce the gap there must be a clear understanding of the different factors that explain the inequality of the distribution of household work and its persistence.

This paper pursues this objective in the context of families in sub-Saharan Africa. We analyze how household characteristics relate to the unequal distribution of housework between couples in Ethiopia, Ghana, South Africa, and Tanzania. Our work helps with the identification of factors that can be addressed by public policy to achieve a better redistribution of responsibilities, thus reducing women's time poverty.

\footnotetext{
${ }^{1}$ The full text of UN SDG Goal 5 (Achieve gender equality and empower all women and girls) is available at: https:/www.un.org/sustainabledevelopment/gender-equality/
} 
The next section presents a literature review of previous works that attempt to measure and explain the intrahousehold allocation of housework, with a special focus on Africa. We then proceed to present the econometric model that will be the theoretical background of our data analysis. Data and summary statistics are exposed and the results of the model are presented in the following section. We then offer our concluding remarks.

\section{LITERATURE REVIEW}

\subsection{Theoretical Perspectives}

Several theoretical models have been developed to explain the distribution of unpaid household work within couples, following the experience of families and households in the global North. These models rely on different explanatory theories from which three have gained currency in the literature. These are the time availability theory, the resource theory, and the gender ideology theory.

The time availability theory hypothesizes that among couples, the partner who spends more time in paid employment outside the home will spend less time on household work (Bianchi 2000; Geist and Ruppanner 2018; Gough and Killewald 2010; Lachance-Grzela and Bouchard 2010). Since the number of hours in a day is fixed, time spent in paid employment reduces the available amount of time spent on housework. This raises the question of what determines who will spend more time in paid employment outside the home.

In the African context, the time availability theory should be framed differently because paid employment is not as common as in more developed economies and other types of employment arrangements are more prevalent. Self-employment provides greater flexibility to negotiate time spent on domestic work, because of the fewer restrictions regarding how to arrange the working day. In rural areas, working for the family business (mostly own farms) may provide even greater work flexibility, but may also increase the likelihood of a double burden for women who can now work on the farm while maintaining the hours of commitment to household production. 
While employment arrangements, such as self-employment or part-time jobs, may increase the likelihood of husbands taking more of the responsibility of household production, they may not have the same effects for women. The increase of flexible work arrangements may simply increase the time burden she may face, as was reported in Zacharias et al. (2018).

Resource-based theories take into account more explicitly the unequal distribution of power that may explain the distribution of unpaid care work. The partner with the greater share of financial resources is thus endowed with greater bargaining power to negotiate for less time spent on housework (Brines 1994; Geist and Ruppanner 2018). It is expected that as women's earnings increase relative to their spouses' they will spend less time on housework compared to their spouses. It is also expected that as women's absolute earnings increase, they spend less time on housework because they can afford to acquire labor-saving devices and outsource some domestic chores (Gupta 2006), although similar income effects should be observed if overall household income increases.

The resource-based theories have been criticized because of the focus on the couple (Geist and Ruppaner 2018), whereas for the sub-Saharan African context, households with extended family members are more common and offer additional networks for supporting housework while introducing more bargaining agents in the household. ${ }^{2}$ Even within nuclear households, resourcebased theories do not consider children's participation in housework and childcare (Geist and Ruppanner 2018). This is particularly important in the sub-Saharan African context, where children are usually responsible for activities such as cleaning, fetching water and firewood, or taking care of younger siblings. By delegating these tasks to children, the time adult women spend performing these chores may decrease, although it would also create an additional burden on children, reducing their opportunities for education (Sawo 2020).

In addition to resources, gender norms and values can also influence women's bargaining power as well as the conclusions predicted by the time availability theory. Gender ideologies influence how men and women perceive themselves and the roles they consider they must perform within

\footnotetext{
${ }^{2}$ For the present article, we avoid this problem by focusing exclusively on nuclear households in all countries of analysis.
} 
the household. The gender display theory recognizes the role of social norms and perceives housework as a symbolic enactment of gender relations where attitudes about gender roles drive couples to display their "proper" roles in the household (breadwinner husband and homemaker wife under the current social convention), with few families that deviate from the "norm."

Another unconventional behavior observed is that some women do more housework than predicted by their labor market work hours and relative resource models when their income increases. One explanation provided for this phenomenon, the compensatory gender display theory, is that women would put more hours of housework to "prove themselves" as a good wife once a certain level of income has been achieved (e.g., Evertsson and Nermo 2004; Shelton and John 1996; Zuo and Bian 2001). Killewald and Gough (2010), who explore this hypothesis, find no evidence to support the compensatory gender display theory. They do find that as women's earnings increase the time spent on housework decreases but at a declining rate.

In sub-Saharan Africa, gender norms that prescribe specific roles and functions to women and men are still quite pervasive (Feinstein, Feinstein and Sabrow. 2010). The next section will examine the existing literature on the distribution of household chores between men and women in sub-Saharan Africa with a focus on Ethiopia, Ghana, Tanzania, and South Africa.

\subsection{Empirical Literature}

There is limited literature discussing the distribution of unpaid care work between women and men in sub-Saharan Africa, mostly due to restricted availability of time use surveys. Data on how individuals allocate their time across paid work, unpaid work, leisure, and personal maintenance can be obtained from time use surveys designed for this purpose and from time use modules included in household surveys. Labor force surveys sometimes contain modules that collect information on how much time respondents spend on these activities. In a few cases, household production activities recorded in time use surveys have been integrated into national accounting systems in an attempt to monetize their contribution and compare the distribution of paid and unpaid work among men and women (Mitik and Decaluwe 2009; Oosthuizen 2018; Amporfu et al. 2018). 
In most instances, the analyses on the distribution of unpaid care work have been descriptive and based on gender, age bracket, and other socioeconomic variables. Studies that use econometric regressions in estimating the determinants of unequal distribution of unpaid care work in subSaharan Africa are relatively few (Getahun 2018; Costa et al. 2009; Robles 2010; Simister 2013; Wodon and Ying 2010; Lawson 2008; Arora 2015; Herrera and Torelli 2013; Ndlovu, Mohapatra, and Luckert 2018). Most empirical analyses use standard linear regression models to analyze how hours are allocated, but some have also used binomial models (probit/logit) as well as censored regression model (Tobit) for the same purpose (Robles 2010; Wodon and Ying 2010; Getahun 2018; Costa et al. 2009). While linear regression models have been preferred for the analysis of women's household production, as most women engage in some level of household production, Tobit models are usually preferred when analyzing hours of allocation among men, because of the high rate of men with zero hours of household production. Some studies, however, attempt to account for possible sample selection problems, addressing the fact that decisions of how many hours to dedicate to household production may not be exogenous (Herrera and Torelli 2013; Costa et al. 2009; Simister 2013), but indicate that the main challenge is finding appropriate instruments for the analysis.

In general, most descriptive studies on household production indicate, as no surprise, that women have greater involvement in domestic and care activities than men. Charmes (2006) finds women engage about 4.7 times more in Madagascar, nearly 3.8 times more in Mauritius, 3.04 times more in South Africa, and 3.1 times more in Benin. Fontana and Natali (2008), for the case of Tanzania in 2006, also finds that women spent triple the time men do on household activities and care. Robles (2010) finds similar results for Ethiopia, where women spend 36 hours on household production per week, with men spending only 7 hours per week. Fontana and Natali (2008) find the lowest ratio in Ghana, where women spent 5 hours and 42 minutes a day on household activities compared to 3 hours and 8 minutes by men. Using data on time use for Mozambique, Arora (2015) finds that men spend about 1.5 hours per day on household work while women spent almost five times more (7.6 hours). 
Other activities related to household procurement, such as fetching water and wood, have also shown similar patterns. Floro and Komatsu (2011), using the 2000 South Africa National Time Use Survey, estimate that women spend 14.43 minutes per day finding fuel and collecting water compared to men's 5.71 minutes per day. In Tanzania, Fontana and Natali (2008) report that women spend an average of 30 minutes per day collecting water compared to 20 minutes by men, with similar figures for wood collection. Fetching of water and collecting firewood was also noted to be associated with children's household responsibilities. Charmes (2006) reports that in Benin girls and boys aged 7-14 spend 46 minutes and 19 minutes per day, respectively, in fetching water; in Madagascar, girls spent 31 minutes and boys 16, while in Ghana they spent 41 minutes and 38 minutes, respectively, in fetching water.

For most countries, participation in unpaid care work and the amount of time women and men spend performing these tasks varies along with the age profile, with some of the largest gaps observed for women around their mid-20s and 30s, though that gap declines as the population ages (Amporful et al. 2018; Mitik and Decaluwe 2009; Oosthuizen 2018).

As described before, the research on household time allocation has been limited by data availability in terms of time use data and access to information on individual earnings, individual asset wealth, or gender ideology variables. Nevertheless, there have been many studies that have attempted to provide empirical support to the competing theories regarding time allocation: time availability, bargaining, and resource availabilities, and the role of norms/gender ideology.

A recent study on Ethiopia by Getahun (2018) investigated the determinants of women's unpaid care work employing a multivariate hierarchical linear regression model. The study finds that women's employment status, years of schooling, and loan receipt status have a negative significant association with housework time while traditional gender perception/practice has a weak significant positive association with housework time, thus supporting all three theoretical propositions. Wodon and Ying's (2010) study of Sierra Leone finds that people who worked in the past 12 months spend less time on domestic work than the inactive in urban areas, although the opposite is found in the rural areas. 
Some support for the economic bargaining model has also been provided by Ndlovu, Mohapatra, and Luckert (2018). Using a regression discontinuity design and data for rural South Africa, the authors find that increases in women's financial resources (pensions) reduce men's leisure time and increases the time they spend on domestic work. In contrast, increases in men's resources increase women's leisure and reduce their time spent on domestic work.

There are mixed findings for the relationship between women's and men's education and time they spend on housework, as it can affect time allocation through changes in gender ideology, as well as increased financial resources and bargaining. Getahun (2018), using data for 502 married women in Bahir Dar and rural villages in northwest Ethiopia, finds that a husband's education has no effect on the wife's time spent on housework, whereas there is a negative relationship between a wife's education and her time spent on housework. Robles (2010) finds similar results for women in urban and rural Ethiopia. In Ghana (Costa et al. 2009) the negative effects of education were only observed for the highest levels of education, whereas in Sierra Leone (Wodon and Ying 2010) more educated women spend more hours on household production, but only in rural areas.

The relationship between housework and social norms has often been looked at through the lens of the "doing gender" and gender perspectives (Robles 2010; Simister 2013; Ferrant and Thim 2019), and often "all household activities are predominantly considered feminine" (Robles 2010, 308). Ferrant and Thim (2019) note that higher levels of economic development do not lead to a more equal redistribution of unpaid care work between men and women, which was attributed to the persistence of restrictive gender norms.

In addition to the theories of time availability, bargaining power, and gender roles, the empirical research has also explored the role of other individual or household characteristics and their effect on the distribution of time between men and women in the household. The presence of other household members, like children and other adults, dilutes the time availability theory's validity since other household members can perform household tasks in addition to the head of the household and their spouse. 
In general, the presence of young children in the household increases the time women spend on household production, with extensive evidence from Ghana (Costa et al. 2009), Ethiopia (Robles 2010; Getahun 2018), and Sierra Leone (Wodon and Ying 2010). In contrast, the number of children under the age of six years does not appear to affect the time men spend on housework, with only limited evidence to the contrary.

As children grow older and can participate in household chores, the time spent on these chores by adults would be expected to decline, with evidence showing mixed effects for men and women. In Ghana, the presence of children aged between 7 and 10 years increased women's housework time (Costa et al. 2009) but had no effect on men's time. In contrast, in Sierra Leone, children aged 6-14 years were associated with a decline in time spent on housework by rural women and men (Wodon and Ying 2010) but had no effect in urban areas. In Ethiopia, rural and urban men spent less time on housework as the number of children in the household aged 6-14 increased, while there was no effect for women (Robles 2010). Mitik and Decaluwe (2009) noted that as time passes by, children (especially girls) become substitutes for parents in unpaid work, allowing women to increase their market labor supply.

The burden of housework can be reduced for the individual woman and man if other household members can assist with these tasks, although it may also increase the required time of household production, which can have mixed effects on the couple's allocation of household work. In Ethiopia, an increase in the numbers of adult men in the household tends to increase women's time spent on housework while an increase in the number of women, irrespective of their age, is associated with a decline in women's and men's time spent on housework (Robles 2010). The presence of other members in the household (extended family or other adults) has a statistically negative association with women's housework time in many sub-Saharan African countries (Getahun 2018; Wodon and Ying 2010).

A final set of factors that may affect the household's hours allocation is access to basic services and structure of the house where they live. Arku and Arku (2013) explore the role of the housing structure in which couples reside and how it affects the type and amount of housework that men and women are willing and able to do. Their results suggest that residents in self-contained 
houses, which may have the greatest degree of privacy, reported the highest rates of men being involved with housework. Herrera and Torelli (2013) also found that women living with extended families, as well as those in polygamous households, contribute less time to domestic work compared to other households.

Access to and availability of utility services, such as water and electricity, have been found to reduce the burden of housework for both men and women (Arku 2010; Wodon and Ying 2010; Costa et al. 2009; Charmes 2006; Lawson 2008; Fontana and Natali 2008). Costa et al. (2009) for Ghana and Wodon and Ying (2010) for Sierra Leone show that access to community water supply significantly reduces the time spent by women on other domestic activities, but as the distance to the water source increases, time spent on domestic work also increases but at a declining rate. These authors also indicate that time spent on wage-employment activities increases when households have access to electricity, but there is no effect on the probability of engaging in domestic work.

Our paper contributes to this literature with a focus on the process of the intrahousehold allocation. We analyze the determinants of the distribution of time between married couples in Ethiopia, Ghana, South Africa, and Tanzania. In the next section, we present the bivariate Tobit model that we use to estimate the impact that a group of variables has in the time that husbands and wives dedicate to household production. Furthermore, we find that, to a great extent, their times are complementary.

\section{ECONOMETRIC MODEL: BIVARIATE TOBIT APPROACH}

Consider a family's decision process in determining household production responsibilities, i.e., the intrahousehold work time allocation, under the assumption that hours of market work are exogenous. This determination process can be the result of some type of utility maximization process, such as in a unitary model of the household (Ransom1987; Lundberg and Pollak 1996; Pollak 2005) or the result of a bargaining process (Fortin and Lacroix 1997; Lundberg, Pollak, and Wales 1997; Duflo 2003; Duflo and Udry 2003; Rangel 2006). In this framework, the time 
allocated to household production by all household members is determined either by a single agent that allocates the optimal distribution of responsibilities or through an agreement reached by some type of consensus or negotiating process.

From a structural point of view, in both cases the number of desired/agreed/optimal hours ${ }^{3}$ husband and wife will dedicate to household production will be functions of characteristics that affect their preferences or bargaining power, and a reaction to their partners' decisions regarding their involvements in household production.

Under this assumption, desired hours of household production of the husband and wife living in household $i$ can be written as:

$$
\begin{aligned}
& h_{i, h}^{*}=g_{h}\left(h_{i, w}^{*}, X_{i}\right) \\
& h_{i, w}^{*}=g_{w}\left(h_{i, h}^{*}, X_{i}\right)
\end{aligned}
$$

Where $h_{i, h}^{*}$ and $h_{i, w}^{*}$ are the number of desired hours of household work, and $X_{i}$ is a set of characteristics that contains information about the husband, the wife, and the household, and $g_{h}$ and $g_{w}$ are some linear or nonlinear functions that determine the interrelation process. ${ }^{4}$ Without loss of generality, we can assume that these functions can be written as linear functions of the characteristics such that:

$$
\begin{aligned}
& h_{i, h}^{*}=a_{0}+a_{1} h_{i, w}^{*}+a_{2}{ }^{\prime} X_{i} \\
& h_{i, w}^{*}=b_{0}+b_{1} h_{i, h}^{*}+b_{2}{ }^{\prime} X_{i}
\end{aligned}
$$

Solving the system of equations, it is possible to obtain the analytical solution to the structural form for the set of equations:

\footnotetext{
${ }^{3}$ For simplicity, we will refer to this simply as desired hours of household production.

${ }^{4}$ This particular specification is used for two reasons. One is to elicit the possibility of nonlinear functional relationships between $X$ and $h^{*}$ and establish a structural interrelationship between husband's and wife's preferred hours of housework. As shown later, the model implementation focuses on the reduced form equations that follow a more traditional model specification.
} 


$$
\begin{aligned}
& h_{i, h}^{*}=\frac{1}{1-a_{1} b_{1}}\left(a_{0}+a_{2}{ }^{\prime} X_{i}\right)+\frac{a_{1}}{1-a_{1} b_{1}}\left(b_{0}+b_{2}{ }^{\prime} X_{i}\right) \\
& h_{i, w}^{*}=\frac{b_{1}}{1-a_{1} b_{1}}\left(a_{0}+a_{2}{ }^{\prime} X_{i}\right)+\frac{1}{1-a_{1} b_{1}}\left(b_{0}+b_{2}{ }^{\prime} X_{i}\right)
\end{aligned}
$$

However, unless some further assumptions are imposed on the structural model, this system of equations is not identified. ${ }^{5}$ Instead, we can estimate the reduced form system:

$$
\begin{aligned}
& h_{i, h}^{*}=\alpha_{0}+\alpha_{1}{ }^{\prime} X_{i} \\
& h_{i, w}^{*}=\beta_{0}+\beta_{1}{ }^{\prime} X_{i}
\end{aligned}
$$

which characterizes the desired number of household production hours of husbands and wives. To allow for the presence of unobserved components exogenous to $X_{i}$ to have an effect on the actual number of hours husbands and wives dedicate to household production, and to account for the fact that the allocation of household production hours is a corner solution response because a considerable proportion of people end up allocating no time (zero hours) to household production, actual hours of work will be defined as:

$$
\begin{aligned}
h_{i, h} & =\max \left(h_{i, h}^{*}+\varepsilon_{i, h}, 0\right) \\
h_{i, w} & =\max \left(h_{i, w}^{*}+\varepsilon_{i, w}, 0\right)
\end{aligned}
$$

Assuming that $\varepsilon_{h}$ and $\varepsilon_{w}$ represent all other unobserved factors that affect people's decisions and that they follow a bivariate normal distribution:

$$
\varepsilon_{i, h}, \varepsilon_{i, w} \sim N\left(\left[\begin{array}{l}
0 \\
0
\end{array}\right],\left[\begin{array}{cc}
\sigma_{h}^{2} & \rho \sigma_{h} \sigma_{w} \\
\rho \sigma_{h} \sigma_{w} & \sigma_{w}^{2}
\end{array}\right]\right)
$$

\footnotetext{
${ }^{5}$ To be able to identify all the parameters in the model it is necessary to impose restrictions in the structural model such that some characteristics that affect husbands' hours of production do not have a direct effect on wives' decisions and vice versa. In similar models that estimate household labor supply (Ransom 1987; Heim 2009; Hotchkiss et al. 2012), the usual assumption is that spouses age, education and race do not have an effect on own labor market preferences.
} 
where $\sigma_{h}^{2}$ and $\sigma_{w}^{2}$ are the errors variances, and $\rho$ is errors correlation. These systems of equations can model household production hours using a bivariate Tobit model (Ransom1987; Hotchkiss, Moore, and Rios-Avila, 2012 that maximizes the following likelihood function:

$$
\begin{gathered}
L L=\prod_{i=1}^{n} L_{i}\left(h_{h}^{*}, h_{w}^{*}, \sigma_{h}, \sigma_{w}, \rho\right) \\
L_{i}\left(h_{h}^{*}, h_{w}^{*}, \sigma_{h}, \sigma_{w}, \rho\right)=\left\{\begin{array}{c}
\frac{1}{\sigma_{h} \sigma_{w}} b\left(\tilde{h}_{i, h}, \tilde{h}_{i, w}, \rho\right) \text { if } h_{i, h}>0 \text { and } h_{i, w}>0 \\
\frac{1}{\sigma_{h}} \phi\left(\tilde{h}_{i, h}\right) \Phi\left(\frac{\tilde{h}_{i, w}-\rho \tilde{h}_{i, h}}{\sqrt{1-\rho^{2}}}\right) \text { if } h_{i, h}>0 \text { and } h_{i, w}=0 \\
\frac{1}{\sigma_{w}} \phi\left(\tilde{h}_{i, w}\right) \Phi\left(\frac{\tilde{h}_{i, h}-\rho \tilde{h}_{i, w}}{\sqrt{1-\rho^{2}}}\right) \text { if } h_{i, h}=0 \text { and } h_{i, w}>0 \\
B\left(\tilde{h}_{h}, \tilde{h}_{w}, \rho\right) \text { if } h_{i, h}=0 \text { and } h_{i, w}=0
\end{array}\right.
\end{gathered}
$$

where $L_{i}$ is the likelihood function for household $i, L L$ is the product of the likelihood functions across all households, $\tilde{h}_{i, k}=\frac{h_{i, k}-h_{i, k}^{*}}{\sigma_{k}}$ for $k=h, w, 1($.$) is the indicator function, b($.$) and B($. denote the probability density function and cumulative density function for the standard bivariate normal distribution, and $\phi($.$) and \Phi($.$) denote the pdf and cdf for the standard univariate normal$ distribution.

\section{DATA DESCRIPTION AND SUMMARY STATISTICS}

The model is estimated for four countries: Ethiopia (2013), Ghana (2009), Tanzania (2006), and South Africa (2000 and 2010). In this section, we describe the data that was used and how it has been treated and restricted for the estimations. The main data that this work relies on is obtained from time use surveys for the four countries. Time use surveys are conducted at the householdmember level and consist of a 24-hour diary of activity. Each person is interviewed to record the length and type of activities performed during the previous days. 
For our analysis, the samples are being restricted to households where the husband and wife are present, they are between 18 and 75 years old, and have a time diary available. We exclude same-sex couples and households where other adults are present. ${ }^{6}$ For all countries, the activities are recoded as those related to core, care, or procurement following Zacharias et al. (2018), where the sum of all three is considered as the measure of household production. Broadly, activities such as cooking, cleaning, and other household chores are considered core activities; caring for children and adults are part of care activities. Procurement activities consist of shopping and travel time related to shopping as well as time spent on collecting firewood and water. There are certain characteristics of the data that are specific to each country that are described in the following sections.

\subsection{Ethiopia}

The 2013 Ethiopian Time Use Survey (ETUS), conducted by Ethiopia's Central Statistical Agency (CSA), provides all the data for Ethiopia. The questionnaire consists of three parts and was administered to all individuals ages 10 years and older of selected households in 675 enumeration areas, selected based on the 2007 Population and Housing Census of Ethiopia.

The first part of the questionnaire collects information about the socioeconomic and demographic characteristics of the household members. The second part, conducted at the household level, provides information on living conditions and economic assets. The third part consists of an individual diary, where the interviewer collects information from each household member (10 years and older) on how they spent time in each one-hour slot during the previous 24 hours. Except for a few households, the diaries are administered to each member of the household on the same day of the week. After restricting the sample, we are left with 9,250 households out of 12,313 interviewed couple-headed households.

\footnotetext{
${ }^{6}$ Because of this last restriction we lose between 10 percent (South Africa 2000) and 27 percent (Tanzaia and Ghana) of the observations. For more details see, appendix B
} 


\subsection{Ghana}

The 2009 Ghana Time Use Survey (GTUS), organized by the Ghana Statistical Survey (GSS) consists of two questionnaires conducted with households sampled from 300 enumeration areas. The household questionnaire provides information about members' characteristics as well as the households living conditions and housing information. The second questionnaire, the individual diary, is administered to members that are 10 years old or older.

The diary consists of one day with 24 slots of one hour each. Except for a few households, the first and last interviews happen on the same date for all members. After restricting the sample, there are 1,037 households out of 1,999 interviewed couple-headed households.

\subsection{Tanzania}

Tanzania's 2006 time use survey is conducted as a module of the Integrated Labour Force Survey (ILFS) and it comprises one-fifth of the ILFS sample, which amounts to a total of 10,553 persons of age 5 years or older in 3,140 households. Each targeted household member was meant to be visited for seven consecutive days, although some were visited on fewer days. They were asked what they had done during each hour of the previous day.

The data is inputted into one four-hour slot (12 am-4 am) and twenty one-hour slots for which respondents can list up to five activities and indicate if they were carried on simultaneously or not. There is also information regarding the month and days in which the diaries were kept making it possible to calculate activities done simultaneously by different members of the household. After restricting the sample, there are 1,303 households.

\subsection{South Africa}

Of all countries in our sample, South Africa is the only one for which we consider data for two different years: 2000 and 2010. In both cases the survey is conducted with households from urban and rural areas of all provinces. Additionally, in 2010, the sample contains households from four different strata: urban formal, urban informal, rural formal, and tribal areas. The questionnaire in both years contains five sections. The first section covers household characteristics and lists all members of the household. From that information, two people (aged 
10 years and over) are randomly selected to be interviewed for the remaining sections. In contrast, the other countries considered in this study collected time use information from all members (apart from the very young) of the household. The survey's second and third sections collect demographic details of each respondent, while the last two sections are the time diaries.

Information on the respondent's activities for 24 hours between $4 \mathrm{am}$ on the day preceding the survey interview and 4am on the day of the interview was collected to construct the time diary. The 24-hour activity diary is divided into 30-minute slots in which up to three activities, done simultaneously, can be recorded. We restrict the sample to households where the two interviewed members are husband and wife. But this may include couples that are not the head of that household. After restricting the sample we have 1,294 households in 2000 and 2,567 in 2010, out of 1,500 and 3,048 couple households, respectively.

\subsection{Country-level Characteristics}

Inequality in sub-Saharan Africa is among the highest in the world (Milanovic 2003), with South Africa displaying one of the highest Gini coefficients and Ethiopia one of the lowest within the region (Adesina 2016). There are, therefore, significant socioeconomic differences in our sample, within and between countries. The urban-rural divide is one of the drivers of inequality within countries. Furthermore, in the case of South Africa, economic variables present high variability across race.

Table 1 presents data for GDP per capita, poverty rate, poverty gap, and the Gini coefficient for each country with urban and rural data when available. South Africa has a much higher GDP per capita than others - thirteen times higher than Ethiopia - nonetheless more than half of its population lives in poverty (twice as much as the other countries). Furthermore, the poverty gap is unusually high, revealing the difficulty of decreasing poverty in this country.

Such discrepancies are exposed by South Africa's Gini coefficient. Another aspect of inequality in South Africa is reflected in racial disparities. While poverty incidence is 1 percent among the white population, it is 64 percent among the black African population (Statistics South Africa 2017). 
Table 1. Selected Socioeconomic Indicators

\begin{tabular}{|c|c|c|c|c|}
\hline & $\begin{array}{c}\text { Ethiopia } \\
\text { 2015/16 }\end{array}$ & $\begin{array}{c}\text { Ghana } \\
\text { 2016/17 }\end{array}$ & $\begin{array}{c}\text { Tanzania } \\
2017 / 18\end{array}$ & $\begin{array}{c}\text { South Africa } \\
2015\end{array}$ \\
\hline $\begin{array}{l}\text { GDP per capita } \\
\text { (constant } 2010 \text { US\$) }\end{array}$ & 570.31 & 1807.06 & 959.35 & 7433.62 \\
\hline \multicolumn{5}{|l|}{$\begin{array}{l}\text { \% population below } \\
\text { national poverty line: }\end{array}$} \\
\hline Urban area & 15 & 8 & 16 & 41 \\
\hline Rural area & 26 & 40 & 31 & 81 \\
\hline Total & 24 & 23 & 26 & 56 \\
\hline \multicolumn{5}{|l|}{ Poverty gap } \\
\hline Urban area & 6.7 & 1.8 & 3.5 & 27.7 \\
\hline Rural area & 7.4 & 15.1 & 7.4 & 26.5 \\
\hline Total & 3.7 & 8.4 & 6.2 & 28.9 \\
\hline \multicolumn{5}{|l|}{ Gini } \\
\hline Urban area & 0.38 & 0.38 & $0.42 *$ & - \\
\hline Rural area & 0.28 & 0.42 & 0.32 & - \\
\hline Total & 0.33 & 0.43 & 0.38 & 0.68 \\
\hline
\end{tabular}

Ethiopia and Tanzania, with the lowest GDP per capita of the four countries, display the lowest inequality indices. Thus, it seems to be a selected group of the population that drives up the GDP per capita in South Africa and Ghana.

The rural/urban inequality is also more pronounced in Ghana and South Africa, where the difference between poverty rates in urban and rural areas is striking. The Gini coefficients also reveal a different aspect of Ghana - rural areas are more unequal than urban and the higher value of the total Gini shows that income differences between the two areas exacerbate nationwide inequalities.

\subsection{Model Specification and Summary Statistics}

Following the literature, and to keep a model specification that is consistent across countries, we construct a model controlling for age, education level, and employment status of the husband and wife. To allow for a nonlinear effect of age on time allocation, following empirical literature (Robles 2010; Wodon and Ying 2010; Herrera and Torelli 2013), we use quadratic terms and 
interactions between husband and wife's age. We also control for the level of education, but exclude interactions due to small sample size. These two variables may capture the role of bargaining power within the household. In addition, we also control for employment status, distinguishing between nonemployment, paid employment, and self-employment. These variables may capture both financial access's effect on bargaining power and also be a proxy for the time availability theory.

Following the spirit of the role of household structure and the time availability theory, we control for the number of children within the household, distinguishing between young children (ages 0 5) and male and female older children (ages 6-17). This distinction is to allow for the fact that older female children in the household take a larger share of the household responsibilities, often becoming substitutes for the husband and wife.

The mean values of such variables for the four countries are presented in table 2. Ethiopia, with the youngest population and highest average number of children, has a high percentage of the population with low levels of education: only 7 percent of women and 11 percent of men have secondary and tertiary education. Apart from South Africa, self-employment is quite high in all countries, ranging from 62 percent (Ghana) and 85 percent (Ethiopia) for men and 74 percent (Ghana) and 89 percent (Tanzania) for women. 
Table 2. Mean Value of Husband's and Wife's Characteristics

\begin{tabular}{clccc} 
Ethiopia & Ghana & Tanzania & South Africa & South Africa \\
2013 & 2009 & 2006 & 2000 & 2010 \\
\hline
\end{tabular}

Average Age

\begin{tabular}{|c|c|c|c|c|c|}
\hline Husband & 38.6 & 41.2 & 39.3 & 40.4 & 44.0 \\
\hline Wife & 31.0 & 34.4 & 32.0 & 36.1 & 39.7 \\
\hline \multicolumn{6}{|l|}{$\begin{array}{l}\text { Husband's education } \\
\text { (\% pop by level) }\end{array}$} \\
\hline Preschool or no education & 43 & 18 & 18 & 9 & 4 \\
\hline Primary education & 46 & 55 & 15 & 31 & 14 \\
\hline Secondary education & 6 & 15 & 61 & 16 & 34 \\
\hline Tertiary education & 5 & 12 & 7 & 43 & 48 \\
\hline \multicolumn{6}{|l|}{$\begin{array}{l}\text { Wife's education } \\
\text { (\% pop by level) }\end{array}$} \\
\hline Preschool or no education & 68 & 30 & 26 & 9 & 3 \\
\hline Primary education & 25 & 59 & 11 & 26 & 14 \\
\hline Secondary education & 4 & 8 & 59 & 23 & 37 \\
\hline Tertiary education & 3 & 4 & 3 & 42 & 47 \\
\hline \multicolumn{6}{|l|}{$\begin{array}{l}\text { Husband's employment } \\
\text { (\% pop by type) }\end{array}$} \\
\hline Not employed & 2 & 9 & 2 & 25 & 26 \\
\hline Paid employed & 13 & 29 & 15 & 54 & 60 \\
\hline Self employed & 85 & 62 & 83 & 21 & 15 \\
\hline \multicolumn{6}{|l|}{$\begin{array}{l}\text { Wife's employment } \\
\text { (\% pop by type) }\end{array}$} \\
\hline Not employed & 14 & 20 & 9 & 51 & 57 \\
\hline Paid employed & 5 & 7 & 3 & 35 & 34 \\
\hline Self employed & 82 & 74 & 89 & 15 & 9 \\
\hline \multicolumn{6}{|c|}{ Average number of children } \\
\hline All aged $0-5$ & 1.24 & 1.05 & 1.18 & 0.51 & 0.45 \\
\hline Boys aged 6-17 & 0.77 & 0.64 & 0.59 & 0.25 & 0.19 \\
\hline Girls aged $6-17$ & 0.72 & 0.53 & 0.54 & 0.20 & 0.15 \\
\hline Number of observations & 9,250 & 1,037 & 1,303 & 1,295 & 2,567 \\
\hline
\end{tabular}

Note: Values calculated using sample weights. While education has been recoded to be as comparable as possible across all countries, it is not fully comparable; see appendix E for details on education reclassification.

Since the literature has found that household structure and access to basic services can have an impact on the time individuals allocate to household production, we include in the specification controls for close access to water (regardless of the quality), usage of wood as the main source of heating/cooking fuel, and use of electricity as the main source of lighting/heating or cooking. We also control for whether the house is a detached or semidetached unit, except in Ethiopia and 
Tanzania. For Tanzania, we do control for whether or not the household is 30 minutes or less from the closest public transportation.

To capture differences in household wealth, whenever possible we control for consumption per capita, consumption categories, and a wealth index using the information on household assets (appendix C). For Ethiopia and Ghana, we are also able to include controls for the share of controlled assets/expenditures by the women in the household, which should also capture the level of bargaining power that women have. Lastly, we include a dummy variable for urban versus rural locations.

Whenever possible we also control for the household religion and/or ethnicity. In both cases, we expect this qualitative variable may provide a proxy for differences in ideology and traditions across different populations.

The ratios of the population in each of the groups according to household characteristics are reported in table 3. The share of the population with access to water close to or in the house ranges from 21 percent in Ghana to 84 percent in South Africa. Regarding the use of wood and electricity, at one end of the spectrum we have Ethiopia and Tanzania with a large share of the population using wood and a small share with electricity, and South Africa on the other end with 88 percent of the population with electricity and 9 percent using wood. These numbers reflect the level of urbanization, which follows the same trends across these countries.

Data for control of assets and expenditures shows that women control a small share, below 10 percent, in Ethiopia and Ghana. These countries also show a high percentage of Christians in the population, 67 percent, and 69 percent, respectively. Finally, data for race is only available for South Africa. 
Table 3. Household Characteristics, Percent of the Population in Each Group by Country

\begin{tabular}{|c|c|c|c|c|c|}
\hline & $\begin{array}{c}\text { Ethiopia } \\
2013\end{array}$ & $\begin{array}{c}\text { Ghana } \\
2009\end{array}$ & $\begin{array}{c}\text { Tanzania } \\
2006\end{array}$ & $\begin{array}{c}\text { South Africa } \\
\mathbf{2 0 0 0}\end{array}$ & $\begin{array}{c}\text { South Africa } \\
2010\end{array}$ \\
\hline \multicolumn{6}{|l|}{ \% of population that: } \\
\hline Has water access in/or close to the house & 32 & 21 & 23 & 79 & 84 \\
\hline Uses wood & 92 & 45 & 78 & 12 & 9 \\
\hline Uses electricity & 22 & 66 & 11 & 77 & 88 \\
\hline \multicolumn{6}{|l|}{ Lives: } \\
\hline In urban area & 16 & 47 & 24 & 76 & 79 \\
\hline In a house that is a separate unit & & 13 & & 72 & 70 \\
\hline Close to public transportation & & & 82 & & \\
\hline \multicolumn{6}{|l|}{ Belongs to: } \\
\hline Consumption group 1 (lowest) & 32 & 23 & 54 & 29 & 21 \\
\hline Consumption group 2 & 44 & 41 & 30 & 22 & 22 \\
\hline Consumption group 3 & 20 & 24 & 10 & 18 & 30 \\
\hline Consumption group 4 & 4 & 12 & 6 & 24 & 21 \\
\hline Consumption: NA & & & & 8 & 6 \\
\hline \multicolumn{6}{|l|}{ \% controlled by women: } \\
\hline Assets & 5.5 & 7.1 & & & \\
\hline Expenditure & 9.1 & 5.4 & & & \\
\hline \multicolumn{6}{|l|}{ Religion and Race: } \\
\hline Christian & 67 & 69 & & & \\
\hline African Black & & & & 52 & 64 \\
\hline Colored & & & & 3 & 8 \\
\hline Indian or Asian & & & & 12 & 3 \\
\hline White & & & & 33 & 25 \\
\hline $\begin{array}{l}\text { Has wealth index below average } \\
\text {. }\end{array}$ & $\overline{66}$ & 58 & 58 & 46 & $\overline{53}$ \\
\hline
\end{tabular}

Note: Values calculated using sample weights.

Summary statistics for our dependent variables — hours of husband's and wife's household productionare presented in able 4 for all countries. Since there is a large share of households where the husband does zero hours of household production (see table 4), all figures were constrained to data where the husband engages in some positive hours. 
Table 4. Distribution of Hours per Week of Household Production

\begin{tabular}{lrrrrr}
\hline & $\begin{array}{c}\text { Ethiopia } \\
\mathbf{2 0 1 3}\end{array}$ & $\begin{array}{c}\text { Ghana } \\
\mathbf{2 0 0 9}\end{array}$ & $\begin{array}{c}\text { Tanzania } \\
\mathbf{2 0 0 6}\end{array}$ & $\begin{array}{c}\text { South Africa } \\
\mathbf{2 0 0 0}\end{array}$ & $\begin{array}{c}\text { South Africa } \\
\mathbf{2 0 1 0}\end{array}$ \\
\hline $\mathbf{p}\left(\mathbf{h}_{\mathbf{h}}>\mathbf{0}\right)$ & 0.50 & 0.43 & 0.81 & 0.64 & 0.58 \\
\hline $\mathbf{p}\left(\mathbf{h}_{\mathbf{w}}>\mathbf{0}\right)$ & 0.96 & 0.96 & 0.99 & 0.97 & 0.96 \\
$\mathbf{p}\left(\mathbf{h}_{\mathbf{h}}>\mathbf{0} \& \mathbf{h}_{\mathbf{w}}>\mathbf{0}\right)$ & 0.48 & 0.42 & 0.81 & 0.63 & 0.55 \\
$\mathbf{E}\left(\mathbf{h}_{\mathbf{h}}\right)$ & 10.15 & 4.50 & 7.71 & 9.17 & 9.53 \\
$\mathbf{E}\left(\mathbf{h}_{\mathbf{h}} \mid \mathbf{h}_{\mathbf{h}}>\mathbf{0}\right)$ & 20.47 & 10.45 & 9.50 & 14.24 & 16.42 \\
\hline $\mathbf{E}\left(\mathbf{h}_{\mathbf{w}}\right)$ & 42.79 & 32.08 & 36.43 & 33.37 & 35.85 \\
\hline $\mathbf{E}\left(\mathbf{h}_{\mathbf{w}} \mid \mathbf{h}_{\mathbf{w}}>\mathbf{0}\right)$ & 44.42 & 33.39 & 36.99 & 34.52 & 37.51 \\
\hline $\mathbf{E}\left(\mathbf{h}_{\mathbf{h}}+\mathbf{h}_{\mathbf{w}}\right)$ & 52.94 & 36.59 & 44.15 & 42.54 & 45.38 \\
\hline $\mathbf{r h o}$ & 0.14 & 0.08 & 0.18 & 0.05 & 0.01 \\
\hline $\mathbf{N o t e}$ & & & & &
\end{tabular}

Note: Values calculated using sample weights.

Overall, as already discussed in section 2, women almost always engage in household production and contribute between 79 percent to 87 percent of all of the household production time. In contrast with standard expectations, hours of husband's and wife's household production show a small but positive correlation for most countries, with the only exception being South Africa in 2010. The likelihood of men not doing any work at home, however, is quite large. It ranges between 18 percent (Tanzania) to 55 percent (Ghana).

To understand the higher probability of men engaging in household production in Tanzania, it should be taken into consideration that for this country, time use data were collected over seven days, increasing the likelihood of men doing some household work.

Figure 1 provides a representation of the distribution of hours of household production for all countries in our sample, where darker areas represent higher density. Based on the data, a typical woman in our sample works between 20 hours to 60 hours per week, whereas men typically work at home fewer than 10 hours per week. Even when conditioning on doing some household production, husbands do less than half of what women do, with average hours of household production ranging from 9.6 hours (Tanzania) to 20.6 hours (Ethiopia). 
Figure 1. Distribution of Hours per Week of Household Production
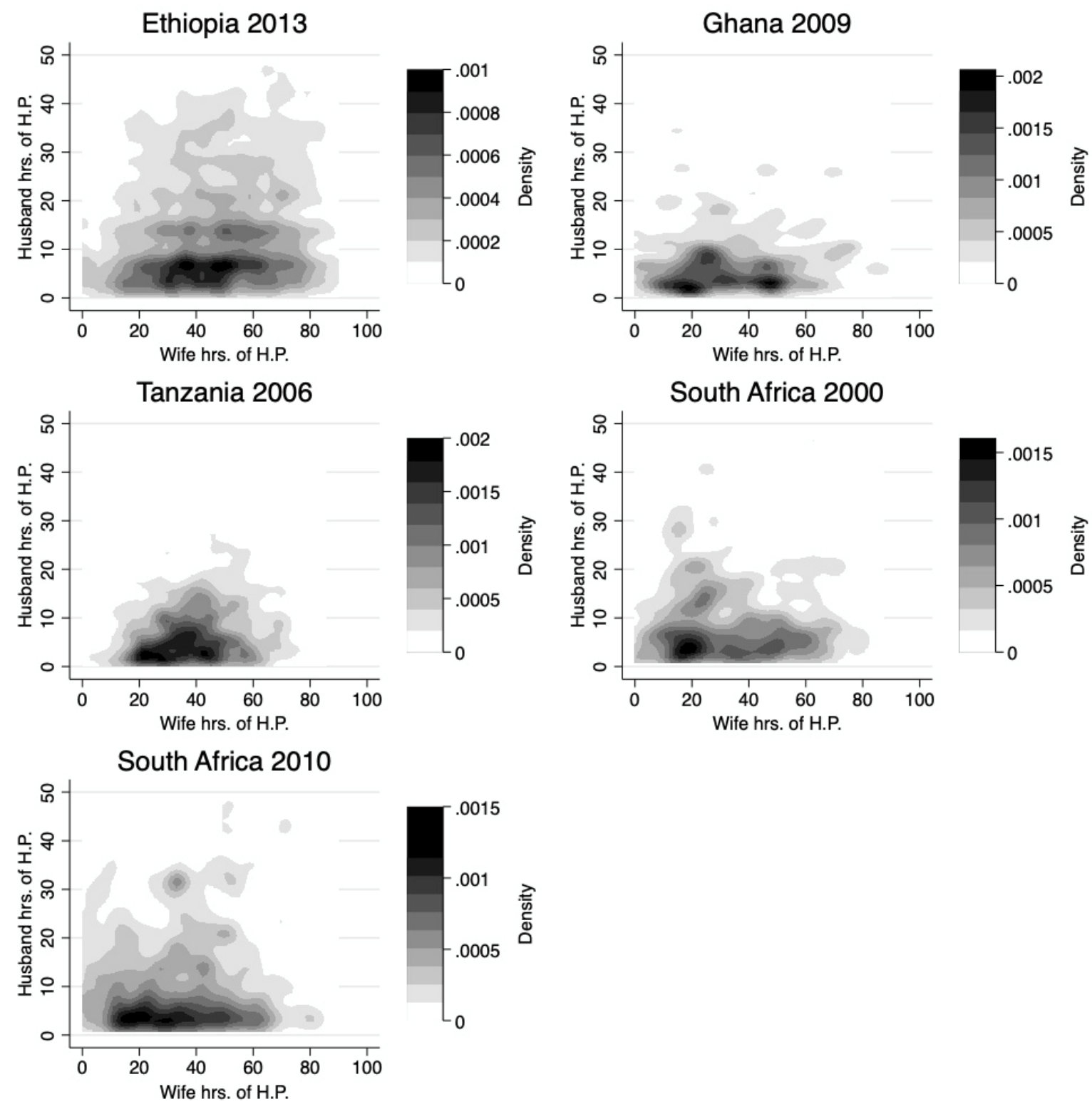

Note: H.P. $=$ household production 


\section{RESULTS: DETERMINANTS OF HOURS OF HOUSEHOLD PRODUCTION}

Table A1 in the appendix reports the full set of coefficients of the reduced form bivariate Tobit model, using the model specification discussed in section 3. The model was estimated using full information maximum likelihood, using the Stata community-contributed command -mbitobit(Rios-Avila 2020). Tables 5-13 provide the partial effects on selected outcomes with plots in figures 2-4. In all cases, partial effects on husband's or wife's hours of housework are estimated as unconditional of their spouse's decisions. They should be considered as the expected effect of a husband or wife taken at random from the population. In addition, the dependent variable in all models is the number of hours of household production per week.

\subsection{The Role of Age}

The first factor we analyze is the role of age and relative age and its impact on the distribution of responsibilities between husband and wife (table 5). Following the literature, we allow for nonlinear effects of age by including husband and wife age in levels, their squares, and firstorder interaction. Based on the literature, age and relative age (how old/young is the wife compared to the husband) can be considered as proxies for bargaining power. One may expect the older the household's husband or wife is, the more likely it is for them to have more bargaining power, increasing the spouse's hours of work and reducing their own.

The estimations for the sub-Saharan African countries seem to largely support this hypothesis, but with heterogeneity across countries. In Ethiopia, the older the husband, the fewer hours he contributes to household production. On average, each additional year of age reduces their contributed time by just less than 0.14 hours ( $\sim 9$ minutes) per week. While there are some similar effects for South Africa (2010) and Ghana, the magnitudes are much smaller and not statistically significant.

We find stronger evidence across countries that husbands' age positively impacts the number of hours wives dedicate to household production. In Ethiopia and South Africa (2000 and 2010), each additional year of age of the husband increases the expected number of hours wives engage in household production by 0.25 hours ( $\sim 15$ minutes) per week. The net effect is that the share of 
hours of household production that falls under wives' responsibilities increases with husbands' age, although the effect is significant only in Ethiopia and South Africa (2010). In these countries, each additional year of a husband's age increases the wife's share by $0.22-0.30$ percentage points.

Turning our attention to the wife's age, we would expect that bargaining power would increase as she gets older, or the older she is compared to her husband, reducing her time contributions to household production and increasing her husband's contributions. The estimates provide mixed evidence of this. Across all countries, we observe that a wife's age has a negative effect, albeit small and not statistically significant, on the expected number of hours a husband works. The exception is Tanzania, where the estimated effect is marginally significant, but the size of the effect is small (about 0.08 hours or 5 minutes per week decline by an additional year of age).

The evidence is somewhat more consistent when concentrating on the effect of her hours of work. We find that across all countries, the older women are, the less time they engage in household production, but this effect is only significant for Ethiopia and Tanzania. Each additional year of age reduces the expected time engaged in household production by 0.38 hours (23 minutes) per week in Tanzania and 0.58 hours (34 minutes) per week in Ethiopia. Since husbands' time declines with wives' age, except for Ethiopia, we do not observe a decline in the wives' share of hours as they get older. 
Table 5. Marginal Effects of Age

\begin{tabular}{|c|c|c|c|c|c|}
\hline & $\begin{array}{c}(1) \\
\text { Ethiopia } \\
\mathbf{2 0 1 3} \\
\end{array}$ & $\begin{array}{c}(2) \\
\text { Ghana } \\
2009 \\
\end{array}$ & $\begin{array}{c}(3) \\
\text { Tanzania } \\
\mathbf{2 0 0 6} \\
\end{array}$ & $\begin{array}{c}(4) \\
\text { South Africa } \\
\mathbf{2 0 0 0} \\
\end{array}$ & $\begin{array}{c}(5) \\
\text { South Africa } \\
\mathbf{2 0 1 0} \\
\end{array}$ \\
\hline \multicolumn{6}{|l|}{ Husband's age } \\
\hline Hrs of HP husband & $\begin{array}{c}-0.141^{* * *} \\
(0.049)\end{array}$ & $\begin{array}{l}-0.011 \\
(0.068)\end{array}$ & $\begin{array}{c}0.040 \\
(0.036)\end{array}$ & $\begin{array}{c}0.045 \\
(0.133)\end{array}$ & $\begin{array}{l}-0.057 \\
(0.060)\end{array}$ \\
\hline Hrs of HP wife & $\begin{array}{l}0.278^{* * *} \\
(0.069)\end{array}$ & $\begin{array}{l}-0.104 \\
(0.125)\end{array}$ & $\begin{array}{c}0.069 \\
(0.073)\end{array}$ & $\begin{array}{c}0.285^{*} \\
(0.158)\end{array}$ & $\begin{array}{c}0.244^{* * *} \\
(0.094)\end{array}$ \\
\hline Share of HHP wife & $\begin{array}{l}0.300^{* * *} \\
(0.072)\end{array}$ & $\begin{array}{c}0.022 \\
(0.154) \\
\end{array}$ & $\begin{array}{l}-0.040 \\
(0.064)\end{array}$ & $\begin{array}{c}0.089 \\
(0.283)\end{array}$ & $\begin{array}{l}0.230^{* *} \\
(0.105)\end{array}$ \\
\hline \multicolumn{6}{|l|}{ Wife's age } \\
\hline Hrs of HP husband & $\begin{array}{c}0.019 \\
(0.062)\end{array}$ & $\begin{array}{l}-0.043 \\
(0.087)\end{array}$ & $\begin{array}{l}-0.083^{*} \\
(0.047)\end{array}$ & $\begin{array}{l}-0.039 \\
(0.126)\end{array}$ & $\begin{array}{c}0.041 \\
(0.064)\end{array}$ \\
\hline Hrs of HP wife & $\begin{array}{c}-0.574^{* * *} \\
(0.090)\end{array}$ & $\begin{array}{l}-0.088 \\
(0.153)\end{array}$ & $\begin{array}{c}-0.377^{* * *} \\
(0.094)\end{array}$ & $\begin{array}{l}-0.138 \\
(0.151)\end{array}$ & $\begin{array}{l}-0.081 \\
(0.100)\end{array}$ \\
\hline Share of HHP wife & $\begin{array}{c}-0.235^{* * *} \\
(0.090)\end{array}$ & $\begin{array}{c}0.035 \\
(0.193) \\
\end{array}$ & $\begin{array}{l}-0.002 \\
(0.080)\end{array}$ & $\begin{array}{c}-0.018 \\
(0.264)\end{array}$ & $\begin{array}{l}-0.133 \\
(0.113)\end{array}$ \\
\hline $\mathrm{N}$ & 9250 & 1037 & 1303 & 1294 & 2567 \\
\hline
\end{tabular}

To visualize the impact of a husband's and wife's age and their interaction on hours of household production, using the model estimations, figure 2 presents the average expected number of hours a husband and wife would engage as a function of the wife's age for four different reference points of a husband's age. This helps visualize the age effect previously described, as well as the role of relative age (interaction).

As was previously described, across all countries we observe that age has a strong impact on hours of household production that is consistent with our expectations. Keeping the husband's age fixed, the older their wife is, the more equitable the distribution of hours of domestic work. These scenarios, however, may not be observed because in 80 percent (South Africa 2000) to 97 percent (Ethiopia) of the households in the samples, the husband is older than the wife, with a median age difference of six years.

Taking this into consideration we observe that the plots in figure 2 are consistent with the marginal effects from table 5. For most countries, the older the wife, the more hours the husband will dedicate to household production, reducing the gender gap in their household production contributions. This effect, however, is weaker if the age difference is kept fixed. One case of relevance is Tanzania. Regardless of a husband's age, as shown in table 5, the older the wife is, 
the fewer hours the husband would dedicate to household production. Despite the reduction in hours of domestic work, women's share either remains constant or increases as they get older.

\section{Figure 2. Average Expected Hours of Household Production per Week by Age}
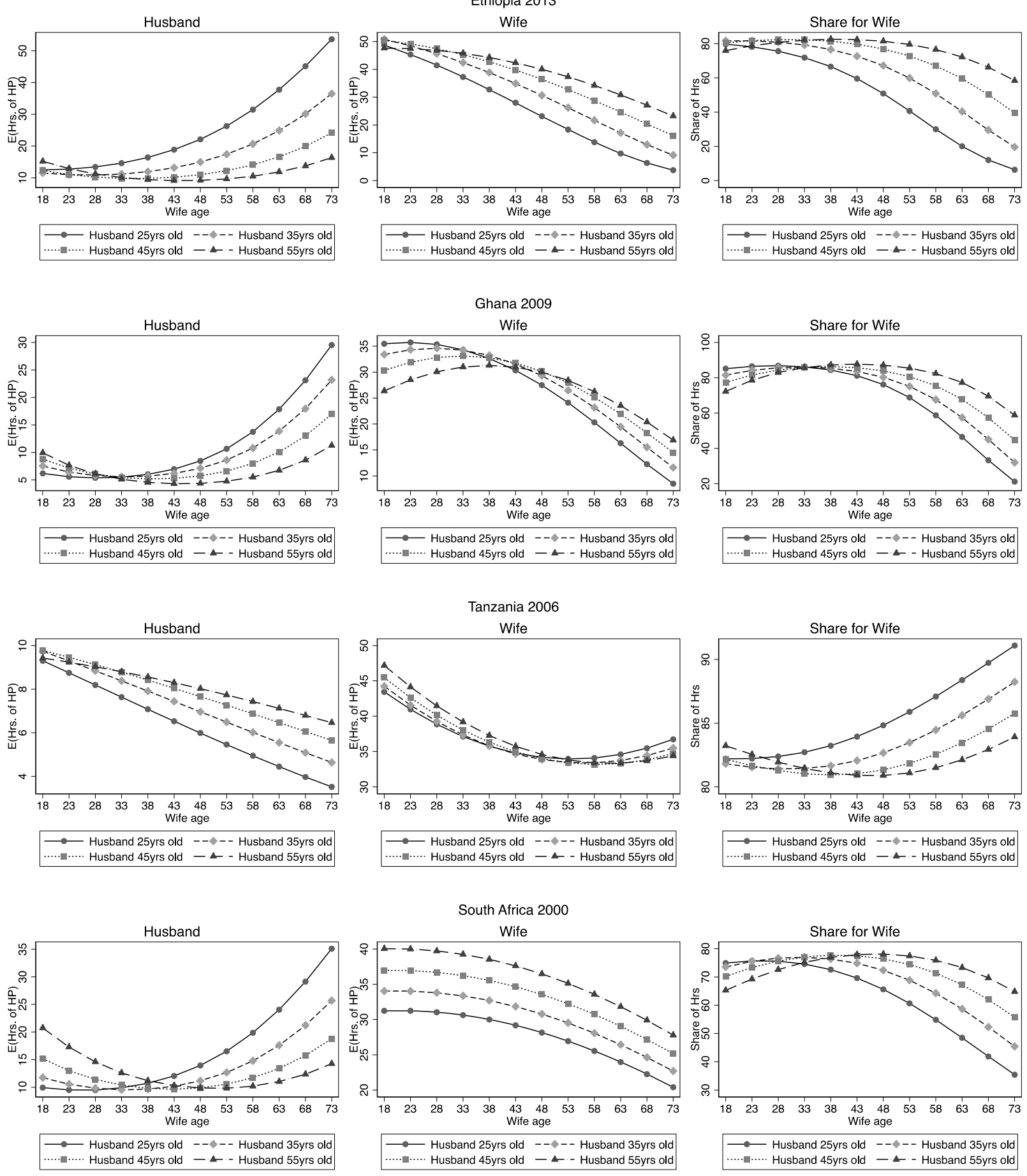

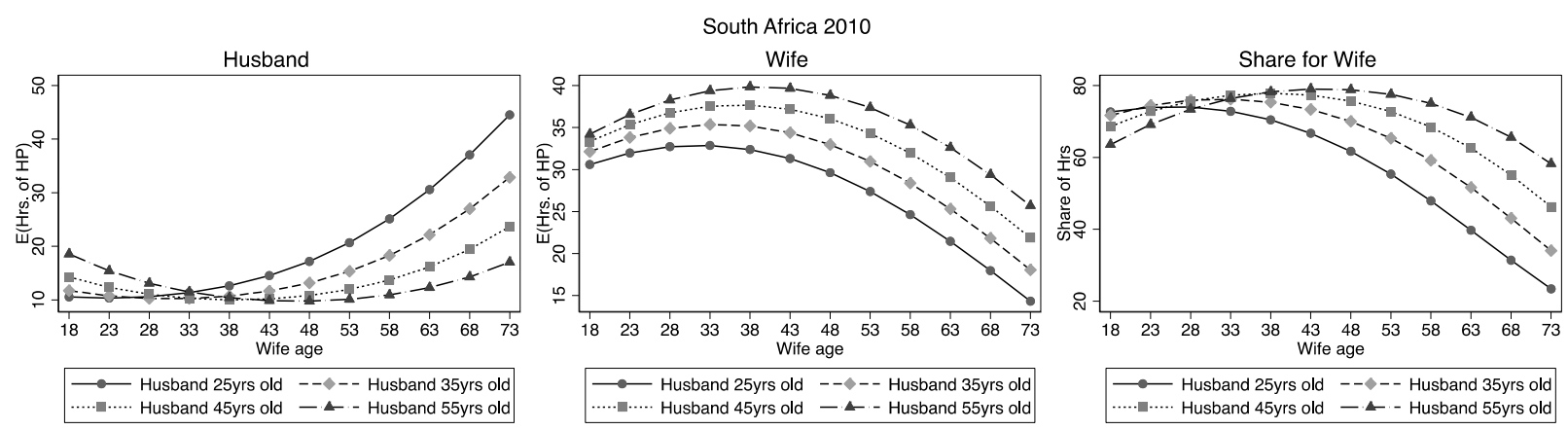

\subsection{The Role of Education}

The level of education of husband and wife can be considered as proxies for two factors that affect the allocation of household production hours. On the one hand, a higher level of education may represent greater bargaining power as it may be closely related to higher earning potential. On the other hand, higher levels of education may expose men and women to different cultural values, which affect their understanding of fairness in the distribution of rights and responsibilities within the household (Vella 2004). In our model specification, categorical values classifying the education level of the husband and wife are included to capture these effects. However, due to data constraints, we do not include interactions between their levels of education. The results are presented in table 6 .

Across all countries, we use husbands and wives with no formal education or with only preschool education as the baseline. There is a substantial proportion of individuals with such a low level of educational attainment in Ghana, Ethiopia, and Tanzania (see table 2). Higher levels of husband's education seem to have no significant effect on the allocation of household production hours when compared to the predicted hours of household production among husbands with no education.

The only exception is observed for South Africa (2010), where approximately 4 percent of the population falls within the baseline education level. The estimates for this country suggest that when husbands with secondary education dedicate 2.5 more hours to household production per week, their wives experience a nonsignificant decline of 1.5 hours per week, which can potentially contribute to a 5 percentage point decline in the share of hours women engage in household production. Albeit similar in direction and magnitude, no significant differences are 
observed for households where the husband has a tertiary level of education of higher. ${ }^{7}$ We also observe that in Ghana, when the husband has a tertiary level of education, the model suggests that his hours of work will decline and his wife's will increase, generating a positive, but marginally significant, effect that increases women's share of hours. Focusing on points estimates and setting Ghana aside, there is some weak evidence that when husbands have more education, they do more work at home and wives' hours decline slightly, reducing the gender gap of hours allocated to household production.

We next turn our attention to the wife's education. Compared to husband's education, this variable has a more consistent impact on the allocation of hours, reducing the time spent by women on household production and increasing men's time. This reflects the positive impact that women's educational achievements have on their bargaining power. For Ethiopia, Ghana, Tanzania, and South Africa (2000) we observe that the higher a women's education level, the fewer hours they engage in household production, while husbands invest more hours doing so (or reduce their hours in a less-than-proportional manner). The net effect is a decline in the share of hours of household production done by women.

It is interesting to notice that the large effects estimated for Ghana were not generated by a reduction in hours of household work by women. On the contrary, the model suggests that compared to noneducated women, those with tertiary education do seven additional hours of work in the household. Nevertheless, the large standard errors make this effect not statistically significant. Furthermore, the positive impact on men's hours of household production (double) more than compensates the original effect of women's longer working hours. It is also noticeable that the increasing hours of household work by educated women is observed in South Africa in 2010 as well, but without the counterbalancing impact on men's hours of work. It may be possible that for Ghana and South Africa (2010) the estimations regarding education are consistent with compensatory gender display theory, which states that a wife that earns more than her husband does a larger fraction of housework to "prove herself" as a good woman (Evertsson and Nermo 2004; Shelton and John 1996; Zuo and Bian 2001). However, it could

\footnotetext{
${ }^{7}$ It should be noticed that, except for South Africa, a very small percentage of the population achieves a tertiary level of education in these countries, which may partially explain the lack of significance level for some variables in the models.
} 
also be that in Ghana, women with a tertiary education are more likely to be in paid employment outside the home, and if they work longer hours than their spouses, men may be required to participate in housework. It should be noticed that, on average, there is a larger proportion of more-educated wives than husbands in South Africa compared to Ghana.

Table 6. Marginal Effects of Education

\begin{tabular}{|c|c|c|c|c|c|}
\hline & $\begin{array}{c}(1) \\
\text { Ethiopia } \\
2013\end{array}$ & $\begin{array}{c}(2) \\
\text { Ghana } \\
\mathbf{2 0 0 9}\end{array}$ & $\begin{array}{c}(3) \\
\text { Tanzania } \\
\mathbf{2 0 0 6}\end{array}$ & $\begin{array}{c}(4) \\
\text { South Africa } \\
2000\end{array}$ & $\begin{array}{c}(5) \\
\text { South Africa } \\
2010\end{array}$ \\
\hline \multicolumn{6}{|l|}{ Husband's education } \\
\hline \multicolumn{6}{|c|}{ Base: Preschool or no education } \\
\hline Hrs of HP husband & $10.962^{* * *}$ & $6.135^{* * *}$ & $8.125^{* * *}$ & $9.459^{* * *}$ & $9.079^{* * *}$ \\
\hline Hrs of HP wife & $44.532^{* * *}$ & $32.482^{* * *}$ & $39.082^{* * *}$ & $32.532^{* * *}$ & $37.751^{* * *}$ \\
\hline Share of HHP wife & $80.395^{* * *}$ & $84.190^{* * *}$ & $82.496^{* * *}$ & $76.461^{* * *}$ & $79.493^{* * *}$ \\
\hline \multicolumn{6}{|l|}{ Primary education } \\
\hline Hrs of HP husband & $\begin{array}{c}-0.279 \\
(0.463)\end{array}$ & $\begin{array}{c}-0.760 \\
(1.010)\end{array}$ & $\begin{array}{c}0.250 \\
(0.784)\end{array}$ & $\begin{array}{c}-0.041 \\
(1.349)\end{array}$ & $\begin{array}{c}0.183 \\
(1.368)\end{array}$ \\
\hline Hrs of HP wife & $\begin{array}{l}-0.000 \\
(0.673)\end{array}$ & $\begin{array}{c}-0.463 \\
(1.863)\end{array}$ & $\begin{array}{c}0.310 \\
(1.474)\end{array}$ & $\begin{array}{c}-1.051 \\
(2.400)\end{array}$ & $\begin{array}{l}-2.686 \\
(2.696)\end{array}$ \\
\hline Share of HHP wife & $\begin{array}{c}0.407 \\
(0.692) \\
\end{array}$ & $\begin{array}{c}1.509 \\
(2.440) \\
\end{array}$ & $\begin{array}{l}-0.319 \\
(1.418)\end{array}$ & $\begin{array}{c}-0.584 \\
(2.258)\end{array}$ & $\begin{array}{l}-1.690 \\
(2.870) \\
\end{array}$ \\
\hline \multicolumn{6}{|l|}{ Secondary education } \\
\hline Hrs of HP husband & $\begin{array}{c}0.718 \\
(1.006)\end{array}$ & $\begin{array}{c}-0.577 \\
(1.387)\end{array}$ & $\begin{array}{c}0.798 \\
(0.688)\end{array}$ & $\begin{array}{c}0.869 \\
(1.764)\end{array}$ & $\begin{array}{c}1.782 \\
(1.415)\end{array}$ \\
\hline Hrs of HP wife & $\begin{array}{c}0.807 \\
(1.410)\end{array}$ & $\begin{array}{c}1.734 \\
(2.762)\end{array}$ & $\begin{array}{c}-0.453 \\
(1.281)\end{array}$ & $\begin{array}{c}4.884 \\
(3.084)\end{array}$ & $\begin{array}{l}-1.717 \\
(2.857)\end{array}$ \\
\hline Share of HHP wife & $\begin{array}{l}-0.730 \\
(1.419) \\
\end{array}$ & $\begin{array}{c}1.953 \\
(3.162) \\
\end{array}$ & $\begin{array}{c}-1.578 \\
(1.229) \\
\end{array}$ & $\begin{array}{c}1.198 \\
(2.824) \\
\end{array}$ & $\begin{array}{l}-3.880 \\
(2.981) \\
\end{array}$ \\
\hline \multicolumn{6}{|l|}{ Tertiary education } \\
\hline Hrs of HP husband & $\begin{array}{c}2.432 \\
(1.512)\end{array}$ & $\begin{array}{c}-2.042 \\
(1.457)\end{array}$ & $\begin{array}{c}-0.333 \\
(0.982)\end{array}$ & $\begin{array}{c}0.659 \\
(2.147)\end{array}$ & $\begin{array}{c}1.138 \\
(1.521)\end{array}$ \\
\hline Hrs of HP wife & $\begin{array}{c}1.504 \\
(1.972)\end{array}$ & $\begin{array}{c}3.874 \\
(4.249)\end{array}$ & $\begin{array}{l}-2.120 \\
(2.117)\end{array}$ & $\begin{array}{c}2.185 \\
(3.791)\end{array}$ & $\begin{array}{l}-2.479 \\
(3.030)\end{array}$ \\
\hline Share of HHP wife & $\begin{array}{l}-2.788 \\
(2.031)\end{array}$ & $\begin{array}{l}5.826^{*} \\
(3.463)\end{array}$ & $\begin{array}{c}-0.241 \\
(1.835)\end{array}$ & $\begin{array}{c}0.102 \\
(3.291)\end{array}$ & $\begin{array}{l}-3.237 \\
(3.141)\end{array}$ \\
\hline \multicolumn{6}{|l|}{ Wife's education } \\
\hline \multicolumn{6}{|c|}{ Base: Preschool or no education } \\
\hline Hrs of HP husband & $10.816^{* * *}$ & $4.703^{* * *}$ & $8.612^{* * *}$ & $10.013^{* * *}$ & $10.165^{* * *}$ \\
\hline Hrs of HP wife & $44.404^{* * *}$ & $32.551^{* * *}$ & $38.220^{* * *}$ & $36.029^{* * *}$ & $29.494^{* * *}$ \\
\hline Share of HHP wife & $80.546^{* * *}$ & $87.360^{* * *}$ & $81.364^{* * *}$ & $77.724^{* * *}$ & $72.444^{* * *}$ \\
\hline \multicolumn{6}{|l|}{ Primary education } \\
\hline Hrs of HP husband & $\begin{array}{c}0.470 \\
(0.523)\end{array}$ & $\begin{array}{c}0.706 \\
(0.756)\end{array}$ & $\begin{array}{c}0.650 \\
(0.924)\end{array}$ & $\begin{array}{c}-1.543 \\
(1.363)\end{array}$ & $\begin{array}{c}-0.414 \\
(1.377)\end{array}$ \\
\hline Hrs of HP wife & $\begin{array}{c}1.167 \\
(0.764)\end{array}$ & $\begin{array}{c}0.257 \\
(1.770)\end{array}$ & $\begin{array}{c}-1.901 \\
(1.481)\end{array}$ & $\begin{array}{c}-0.682 \\
(2.106)\end{array}$ & $\begin{array}{c}3.701 \\
(2.326)\end{array}$ \\
\hline Share of HHP wife & $\begin{array}{c}-0.259 \\
(0.751) \\
\end{array}$ & $\begin{array}{l}-1.532 \\
(1.858) \\
\end{array}$ & $\begin{array}{c}-1.981 \\
(1.573) \\
\end{array}$ & $\begin{array}{c}2.416 \\
(2.333) \\
\end{array}$ & $\begin{array}{c}3.286 \\
(3.209) \\
\end{array}$ \\
\hline Secondary education & & & & & \\
\hline Hrs of HP husband & $\begin{array}{c}0.755 \\
(1.300)\end{array}$ & $\begin{array}{c}0.422 \\
(1.321)\end{array}$ & $\begin{array}{c}-0.087 \\
(0.647)\end{array}$ & $\begin{array}{c}0.678 \\
(1.676)\end{array}$ & $\begin{array}{c}-0.541 \\
(1.439)\end{array}$ \\
\hline Hrs of HP wife & -0.193 & -0.319 & 1.358 & -2.524 & $6.114 * *$ \\
\hline
\end{tabular}




\begin{tabular}{lccccc} 
& $(1.637)$ & $(3.125)$ & $(1.202)$ & $(2.550)$ & $(2.507)$ \\
Share of HHP wife & -1.160 & -1.107 & 0.694 & -2.592 & 4.913 \\
& $(1.797)$ & $(3.254)$ & $(1.143)$ & $(2.854)$ & $(3.435)$ \\
\hline Tertiary education & & & & & \\
Hrs of HP husband & 0.258 & $4.906^{*}$ & -0.298 & 0.267 & 0.692 \\
& $(1.714)$ & $(2.927)$ & $(1.366)$ & $(2.068)$ & $(1.619)$ \\
Hrs of HP wife & -1.366 & 7.751 & -3.145 & -3.299 & $7.273^{* * *}$ \\
& $(2.514)$ & $(6.415)$ & $(2.692)$ & $(2.829)$ & $(2.709)$ \\
Share of HHP wife & -0.886 & -6.528 & -0.836 & -2.341 & 3.478 \\
& $(2.599)$ & $(5.679)$ & $(2.809)$ & $(3.663)$ & $(3.698)$ \\
\hline $\mathrm{N}$ & 9250 & 1037 & 1303 & 1294 & 2567 \\
\hline
\end{tabular}

Note: Standard errors in parentheses; ${ }^{*} \mathrm{p}<0.1,{ }^{* *} \mathrm{p}<0.05,{ }^{* * *} \mathrm{p}<0.01$

\subsection{Time Availability and Employment Status}

A recurrent explanation of household production time allocation is provided by the time availability theory. This theory suggests that because of time constraints imposed by other activities, such as paid work, employed men and women may work fewer hours at home compared to their nonemployed partners. While we cannot control for actual hours of work due to data limitations, it is possible to analyze the support for this theory by including controls on employment status. Specifically, we distinguish between those who are self-employed (which includes unpaid family workers and is the base group), nonemployed (which includes the unemployed), and paid employed (i.e., wage and salary workers). From an intuitive point of view, people who engage in paid employment will face greater constraints in terms of time, consequently working fewer hours at home. Those who are not employed will have the most flexibility to dedicate their time to household production alone. Finally, the self-employed face stricter time constraints than the nonemployed. They are also more likely to have more hours of household production when compared to those engaged in paid employment, as they can potentially do both paid and unpaid work simultaneously (multitasking) if they are working close home or if they take their children along with them.

Table 7 provides the marginal effects of the husband's and wife's employment status. ${ }^{8}$ The estimations show some mixed results. In South Africa (2000 and 2010), just as expected, nonemployed husbands work 3.6 hours (2000) and 7.4 hours (2010) more per week than the selfemployed, while their spouses work fewer hours (2.7 hours and 5.8 hours per week). The net

\footnotetext{
${ }^{8}$ We do not control for combinations of spouses' employment statuses because some combinations have too few observations to warrant identification.
} 
effect is a reduction of 9.5 percentage points and 12.9 percentage points in the share of women's hours of household production. In contrast, in Ethiopia, Ghana, and Tanzania, nonemployed husbands work fewer hours than those who are self-employed, with their spouses increasing their hours of work. While not statistically significant in Ghana and Tanzania, the net effect of a husband's lack of employment is an increase in the share of hours of household production done by women.

Among these three countries, Ethiopia exhibits the most puzzling results. Nonemployed husbands work 4.5 hours less per week than the self-employed, with an effect that is statistically significant even at 1 percent. A more detailed analysis (not shown here) shows that the main driver of this effect comes from the unemployed, rather than those not in the labor force, an effect that is consistent both in urban and rural areas. Gough and Killewald (2011) suggest that because unemployed husbands lose their role as providers for the household, they may resist doing housework and end up doing even less housework than when employed. This can be seen as the male counterpart to the compensatory gender display theory. As Brines (1994) suggest, unemployed husbands might see housework as a further threat to their male identity. Nevertheless, one should consider that only a small proportion of the Ethiopian adult population is classified as a paid employee.

Looking at husbands with paid employment, we observe results that are more consistent with time availability theory. Across all countries, we observe that husbands with paid employment dedicate fewer hours to housework. The effect ranges from a decline of 0.25 hours (15 minutes) per week of housework in Ghana (not significant) to a decline of 2.7 hours in Ethiopia (significant at 1 percent). Only in South Africa (2000) do we observe a large (2.6 hour) nonsignificant decline in hours of work per week. In contrast, the impact on wives' hours of housework is mixed. The model estimates that women in Tanzania dedicate 3.7 more hours per week to household production when the husband works a paid job. While a similar estimate is found for South Africa (2010), the effect is not statistically significant. Contrarily, for South Africa (2000) the estimations suggest that women's domestic work decreased by more than 3 hours when their husbands have a paid job. The effect in Tanzania and Ghana is small. Across all countries, the evidence suggests that when the husband has a paid job, the share of household 
production done by their wives increases between 3.1 percentage points to 5.4 percentage points, except in Ghana, where it only increases by 0.9 percentage points.

Table 7. Marginal Effects of Employment Status

\begin{tabular}{|c|c|c|c|c|c|}
\hline & $\begin{array}{c}(1) \\
\text { Ethiopia } \\
\mathbf{2 0 1 3} \\
\end{array}$ & $\begin{array}{c}(2) \\
\text { Ghana } \\
\mathbf{2 0 0 9}\end{array}$ & $\begin{array}{c}(3) \\
\text { Tanzania } \\
\mathbf{2 0 0 6} \\
\end{array}$ & $\begin{array}{c}(4) \\
\text { South Africa } \\
\mathbf{2 0 0 0} \\
\end{array}$ & $\begin{array}{c}(5) \\
\text { South Africa } \\
\mathbf{2 0 1 0} \\
\end{array}$ \\
\hline \multicolumn{6}{|c|}{ Husband's emp. status } \\
\hline \multicolumn{6}{|l|}{ Not employed } \\
\hline Hrs of HP husband & $\begin{array}{c}-4.472^{* * *} \\
(1.198)\end{array}$ & $\begin{array}{c}-1.218 \\
(1.165)\end{array}$ & $\begin{array}{c}-1.936 \\
(1.865)\end{array}$ & $\begin{array}{c}3.640^{*} \\
(2.153)\end{array}$ & $\begin{array}{l}7.238^{* * *} \\
(1.277)\end{array}$ \\
\hline Hrs of HP wife & $\begin{array}{l}-1.095 \\
(2.220)\end{array}$ & $\begin{array}{c}2.607 \\
(3.592)\end{array}$ & $\begin{array}{c}0.082 \\
(2.560)\end{array}$ & $\begin{array}{c}-5.796^{* *} \\
(2.279)\end{array}$ & $\begin{array}{l}-2.683 \\
(1.706)\end{array}$ \\
\hline Share of HHP wife & $\begin{array}{l}6.630^{* * *} \\
(2.083)\end{array}$ & $\begin{array}{c}3.652 \\
(2.813) \\
\end{array}$ & $\begin{array}{c}3.546 \\
(3.655)\end{array}$ & $\begin{array}{c}-9.552^{* * *} \\
(3.703)\end{array}$ & $\begin{array}{c}-12.664^{* * *} \\
(2.136)\end{array}$ \\
\hline \multicolumn{6}{|l|}{ Paid employed } \\
\hline Hrs of HP husband & $\begin{array}{c}-2.686^{* * *} \\
(0.677)\end{array}$ & $\begin{array}{c}-0.247 \\
(0.894)\end{array}$ & $\begin{array}{c}-1.847^{* * *} \\
(0.548)\end{array}$ & $\begin{array}{c}-2.633 \\
(1.648)\end{array}$ & $\begin{array}{c}-2.456^{* *} \\
(1.003)\end{array}$ \\
\hline Hrs of HP wife & $\begin{array}{c}-0.173 \\
(1.152)\end{array}$ & $\begin{array}{c}0.846 \\
(2.050)\end{array}$ & $\begin{array}{c}3.697^{* * *} \\
(1.263)\end{array}$ & $\begin{array}{l}-3.147 \\
(2.051)\end{array}$ & $\begin{array}{c}2.151 \\
(1.644)\end{array}$ \\
\hline Share of HHP wife & $\begin{array}{l}3.970^{* * *} \\
(1.024)\end{array}$ & $\begin{array}{c}0.886 \\
(2.092) \\
\end{array}$ & $\begin{array}{c}4.590^{* * *} \\
(0.992)\end{array}$ & $\begin{array}{c}3.151 \\
(2.745) \\
\end{array}$ & $\begin{array}{l}5.594^{* * *} \\
(1.745)\end{array}$ \\
\hline \multicolumn{6}{|l|}{ Base: Self employed } \\
\hline Hrs of HP husband & $8.698^{* * *}$ & $5.268^{* * *}$ & $7.078^{* * *}$ & $7.745^{* * *}$ & $7.469^{* * *}$ \\
\hline Hrs of HP wife & $44.524^{* * *}$ & $33.311^{* * *}$ & $41.860^{* * *}$ & $33.908^{* * *}$ & $37.182^{* * *}$ \\
\hline Share of HHP wife & $83.688^{* * *}$ & $86.472^{* * *}$ & $85.369^{* * *}$ & $80.323^{* * *}$ & $81.683^{* * *}$ \\
\hline \multicolumn{6}{|l|}{ Wife's emp. status } \\
\hline \multicolumn{6}{|l|}{ Not employed } \\
\hline Hrs of HP husband & $\begin{array}{l}1.697^{* * *} \\
(0.655)\end{array}$ & $\begin{array}{c}-0.603 \\
(0.884)\end{array}$ & $\begin{array}{c}0.368 \\
(1.007)\end{array}$ & $\begin{array}{c}-1.357 \\
(1.548)\end{array}$ & $\begin{array}{c}-2.206 \\
(1.486)\end{array}$ \\
\hline Hrs of HP wife & $\begin{array}{c}0.462 \\
(1.028)\end{array}$ & $\begin{array}{l}9.179^{* * *} \\
(2.481)\end{array}$ & $\begin{array}{l}5.421^{* * *} \\
(1.812)\end{array}$ & $\begin{array}{l}8.271^{* * *} \\
(2.163)\end{array}$ & $\begin{array}{l}9.560^{* * *} \\
(2.168)\end{array}$ \\
\hline Share of HHP wife & $\begin{array}{c}-2.226^{* *} \\
(0.943)\end{array}$ & $\begin{array}{l}4.107^{* *} \\
(1.816)\end{array}$ & $\begin{array}{c}1.359 \\
(1.717) \\
\end{array}$ & $\begin{array}{l}6.311^{* *} \\
(2.652)\end{array}$ & $\begin{array}{l}7.838^{* * *} \\
(2.463)\end{array}$ \\
\hline \multicolumn{6}{|l|}{ Paid employed } \\
\hline Hrs of HP husband & $\begin{array}{c}4.437^{* * *} \\
(1.416)\end{array}$ & $\begin{array}{c}3.462^{*} \\
(1.771)\end{array}$ & $\begin{array}{c}0.317 \\
(1.581)\end{array}$ & $\begin{array}{c}1.581 \\
(2.029)\end{array}$ & $\begin{array}{c}-0.072 \\
(1.582)\end{array}$ \\
\hline Hrs of HP wife & $\begin{array}{c}-9.634^{* * *} \\
(1.584)\end{array}$ & $\begin{array}{l}-0.846 \\
(3.137)\end{array}$ & $\begin{array}{c}-12.923^{* * *} \\
(2.870)\end{array}$ & $\begin{array}{c}-5.956^{* * *} \\
(2.245)\end{array}$ & $\begin{array}{c}-9.436^{* * *} \\
(2.257)\end{array}$ \\
\hline Share of HHP wife & $\begin{array}{c}-10.839^{* * *} \\
(2.033)\end{array}$ & $\begin{array}{l}-8.014^{*} \\
(4.190)\end{array}$ & $\begin{array}{l}-7.930^{*} \\
(4.114)\end{array}$ & $\begin{array}{l}-7.242^{*} \\
(3.731)\end{array}$ & $\begin{array}{l}-6.766^{* *} \\
(2.687)\end{array}$ \\
\hline \multicolumn{6}{|l|}{ Base: Self employed } \\
\hline Hrs of HP husband & $15.027^{* * *}$ & $8.665^{* * *}$ & $8.905^{* * *}$ & $11.658^{* * *}$ & $11.489^{* * *}$ \\
\hline Hrs of HP wife & $35.392^{* * *}$ & $30.372^{* * *}$ & $25.662^{* * *}$ & $25.784^{* * *}$ & $23.975^{* * *}$ \\
\hline Share of HHP wife & $70.346^{* * *}$ & $77.946^{* * *}$ & $73.671^{* * *}$ & $68.716^{* * *}$ & $67.406^{* * *}$ \\
\hline $\mathrm{N}$ & 9250 & 1037 & 1303 & 1294 & 2567 \\
\hline
\end{tabular}

Note: Standard errors in parentheses; ${ }^{*} \mathrm{p}<0.1,{ }^{* *} \mathrm{p}<0.05,{ }^{* * *} \mathrm{p}<0.01$

Turning to the wives' employment status, results appear more consistent across countries.

Compared to the self-employed, nonemployed women dedicate considerably more hours to housework, except for Ethiopia, where women work only 0.5 more hours (30 minutes) per week 
when not employed. They seem to dedicate between 5.4 to 9.5 more hours to household production, an increase of almost 40 percent compared to the self-employed, supporting the time availability theory. Similarly, hours of housework from husbands seems almost unaffected by women being not employed. The only exception is again Ethiopia. The results suggest that when wives are unemployed, their husbands increase their hours of household production work by 1.7 hours, with a net effect reducing the share of women's hours by 2.2 percentage points.

Lastly, we observe that in most cases husbands increase their hours of work when their wife is engaged in paid employment compared to when they are self-employed. This increase is large and statistically significant in Ethiopia and Tanzania, with a positive but small effect in the other samples. This may suggest that husbands take up some of the housework responsibilities when wives face time constraints due to their paid work. We also see that women reduce their hours of housework substantially, with our estimates suggesting a decrease of between 6 hours to 13 hours of housework per week. We observe that only in Ghana do women experience no change in their number of hours of housework, other factors being constant. Overall, women engaged in paid employment reduce their share of household responsibilities by at least 7 percentage points.

It is interesting to notice that compared to women that are not employed, those that are engaged in paid employment dedicate between 10.1 hours (Ethiopia) to 18.9 hours (South Africa [2010]) fewer per week to housework. Although this implies that the gap in housework is significantly reduced, women may face even more time constraints, if we assume that she works at least 20 hours per week in a part-time job. Furthermore, the additional time husbands dedicate to household production does not compensate for the reduction in the total number of hours the household experiences, therefore falling short from its needs.

\subsection{The Marginal Effect of Children}

One criticism that has been raised in regards to the time constraint theory is that it ignores the presence of other members in the household. While additional members of the household can raise the household's needs, thereby increasing the required hours of household production, additional able members may help reduce the burden by spreading the responsibilities among more people. While we constrain the data to concentrate the analysis on nuclear households 
without extended family members, we can control for the role of the number of children in the household. These results are presented in table 8 and the predicted means in figure 3 .

We first concentrate on analyzing the effects of children under the age of six in the household. Since young children are far less likely to do any contribution to household production, but rather require more attention and care than older children, we expect them to increase necessary hours of housework. Our results corroborate this expectation. Consistent across all countries, a higher number of children under the age of six increases the number of hours of work of husbands and wives, although the effect is small for men in Tanzania and South Africa (2010). While husbands increase their household work contribution by just over one hour per week on average, wives experience an increase in their responsibilities that is at least four times as large. In South Africa (2010), for example, each additional young child increases a wife's household work by almost 8 hours per week compared to the extra 0.6 hours (36 minutes) per week by the husband. While both spouses increase their hours of housework, the net effect is a small but positive change in the share of women's hours of household production (see figure 3).

To analyze the influence of older children and teenagers (ages 6-17 years), we differentiate between boys and girls. Because the children are socialized starting at a young age regarding their gendered roles and responsibilities as household members, the presence of girls and boys has a different effect on husbands' and wives' hours of work. In particular, one might expect that older girls are more likely to share some of the housework responsibilities than boys, reducing the time constrains their mothers face. On the other hand, while boys may also be able to contribute to the household, they likely provide less help with household chores than with the family businesses. This, however, may be reflected in more hours of household production done by the parents, in particular the mother.

Our estimations suggest that the more girls that live in the household, the fewer hours fathers dedicated to household production, but the effect is not significant. In Ethiopia and Tanzania, we find evidence suggesting that as the number of girls increases mothers may experience an average reduction of 1.2 hours (Tanzania) and 1.6 hours (Ethiopia), suggesting girls might be helping with household chores. We do find a puzzling effect that a greater number of girls in the 
household increases the housework hours for women in South Africa. However, it could be because girls in South Africa, at the time of the interview, were more likely to be in school compared to girls in Ethiopia and Tanzania, thus they were unlikely to be available to help their mothers with housework. ${ }^{9}$ This effect, however, could also be driven by the fact that we cannot identify own children in the South African data, but simply all children living in the same household.

The presence of boys between 6 and 17 years of age has a small impact on hours of household production for husbands and wives. As shown in figure 3, the slopes corresponding to them are almost flat. This suggests that while boys are not able to reduce the time responsibilities that women experience, they seem to "take care of themselves," as no additional time responsibilities are imposed on either husband or wife. In South Africa, however, more boys seem to increase the time responsibilities of husbands and wives, which translates into an increase in the share of hours women dedicate to household production.

\footnotetext{
${ }^{9}$ UNESCO data retrieved from The World Bank's data website corroborates this hypothesis. The net enrollement rate of girls of primary school age was 76 percent in Ethiopia in 2012, 72 percent in Ghana 2009, and goes from 86 percent to 87 percent in South Africa between 2000 and 2010. The only caveat is data for Tanzania, which reports a net enrollemnt rate primary school-age girls of 96 percent in 2006. Nonetheless, the Tanzania data shows high fluctuation, registering 54 percent in 2000 and 85 percent in 2013.
} 
Table 8. Marginal Effects of Children

\begin{tabular}{lccccc}
\hline & $\begin{array}{c}(1) \\
\text { Ethiopia } \\
\mathbf{2 0 1 3}\end{array}$ & $\begin{array}{c}(2) \\
\text { Ghana } \\
\mathbf{2 0 0 9}\end{array}$ & $\begin{array}{c}\text { Tanzania } \\
\mathbf{2 0 0 6}\end{array}$ & $\begin{array}{c}(4) \\
\text { South Africa } \\
\mathbf{2 0 0 0}\end{array}$ & $\begin{array}{c}(5) \\
\text { South Africa } \\
\mathbf{2 0 1 0}\end{array}$ \\
\hline \# Children 0-5 & & & & & \\
Hrs of HP husband & $1.167^{* * *}$ & $1.355^{* * *}$ & 0.278 & $1.717^{* *}$ & 0.620 \\
& $(0.228)$ & $(0.384)$ & $(0.271)$ & $(0.723)$ & $(0.530)$ \\
Hrs of HP wife & $4.866^{* * *}$ & $7.900^{* * *}$ & $3.763^{* * *}$ & $7.085^{* * *}$ & $7.882^{* * *}$ \\
& $(0.338)$ & $(0.957)$ & $(0.464)$ & $(1.175)$ & $(0.734)$ \\
Share of HHP wife & 0.062 & -0.012 & $1.044^{* *}$ & 1.034 & $3.351^{* * *}$ \\
& $(0.339)$ & $(0.921)$ & $(0.472)$ & $(1.403)$ & $(1.002)$ \\
\hline \# Girls 6-17 & & & & & \\
Hrs of HP husband & -0.255 & -0.075 & -0.013 & -0.712 & -0.718 \\
& $(0.263)$ & $(0.416)$ & $(0.309)$ & $(0.900)$ & $(0.700)$ \\
Hrs of HP wife & $-1.628^{* * *}$ & -0.003 & $-1.233^{* *}$ & 0.761 & $2.680^{* *}$ \\
& $(0.369)$ & $(0.943)$ & $(0.552)$ & $(1.390)$ & $(1.228)$ \\
Share of HHP wife & -0.217 & 0.168 & -0.478 & 1.714 & $2.708^{* *}$ \\
& $(0.387)$ & $(0.976)$ & $(0.545)$ & $(1.835)$ & $(1.240)$ \\
\hline \# Boys 6-17 & & & & & \\
Hrs of HP husband & -0.145 & 0.438 & 0.171 & $2.533^{* *}$ & -0.993 \\
& $(0.252)$ & $(0.430)$ & $(0.282)$ & $(1.134)$ & $(0.660)$ \\
Hrs of HP wife & -0.222 & 0.657 & -0.080 & $4.691^{* * *}$ & 2.102 \\
& $(0.382)$ & $(0.711)$ & $(0.542)$ & $(1.509)$ & $(1.334)$ \\
Share of HHP wife & 0.131 & -0.734 & -0.330 & -1.812 & $2.849^{* *}$ \\
& $(0.381)$ & $(0.985)$ & $(0.508)$ & $(2.177)$ & $(1.225)$ \\
\hline $\mathrm{N}$ & 9250 & 1037 & 1303 & 1294 & 2567 \\
\hline
\end{tabular}

Note: Standard errors in parentheses; ${ }^{*} \mathrm{p}<0.1,{ }^{* *} \mathrm{p}<0.05,{ }^{* * *} \mathrm{p}<0.01$ 
Figure 3. Average Expected Hours of Household Production per Week by Gender and Age of Children
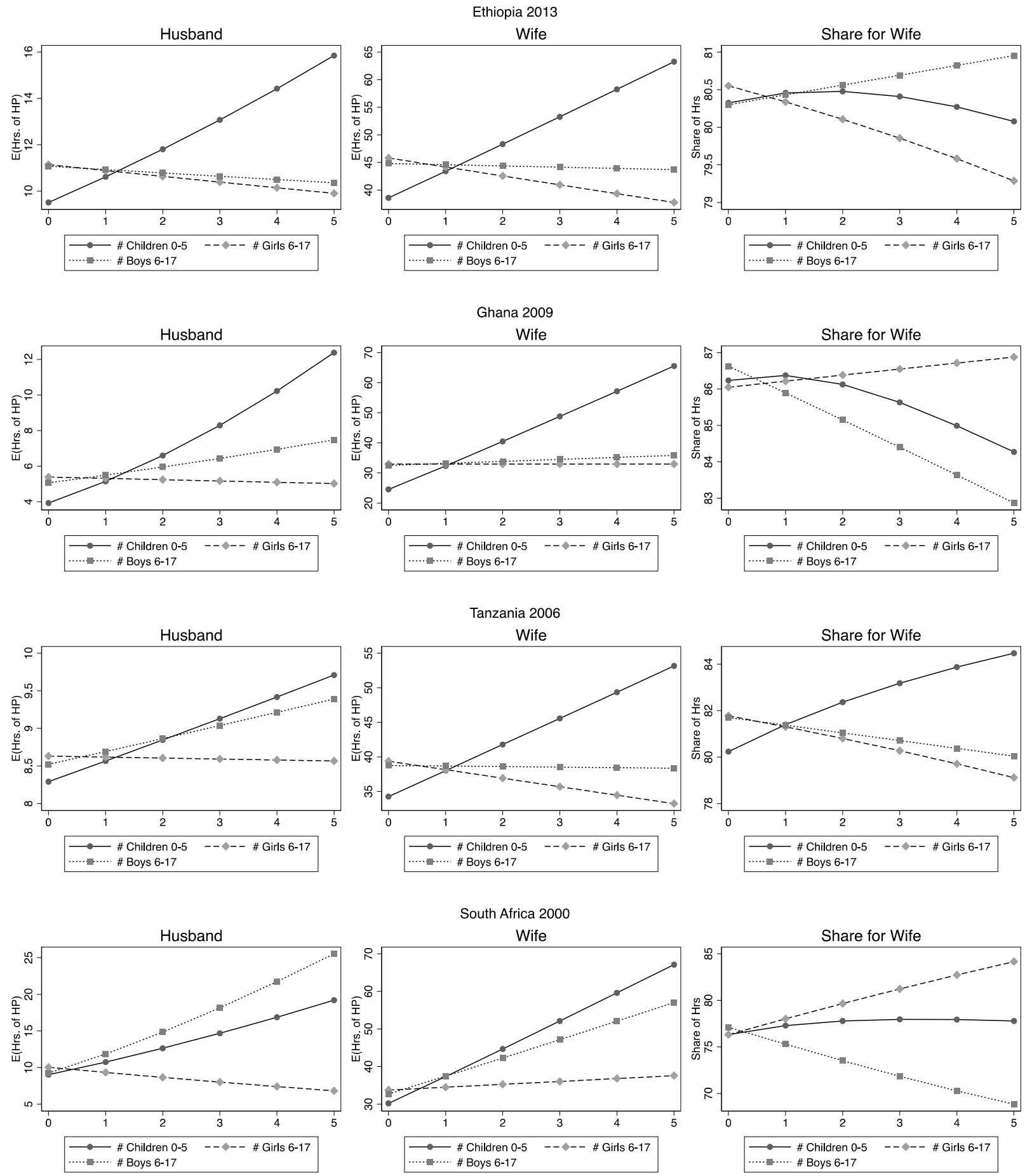

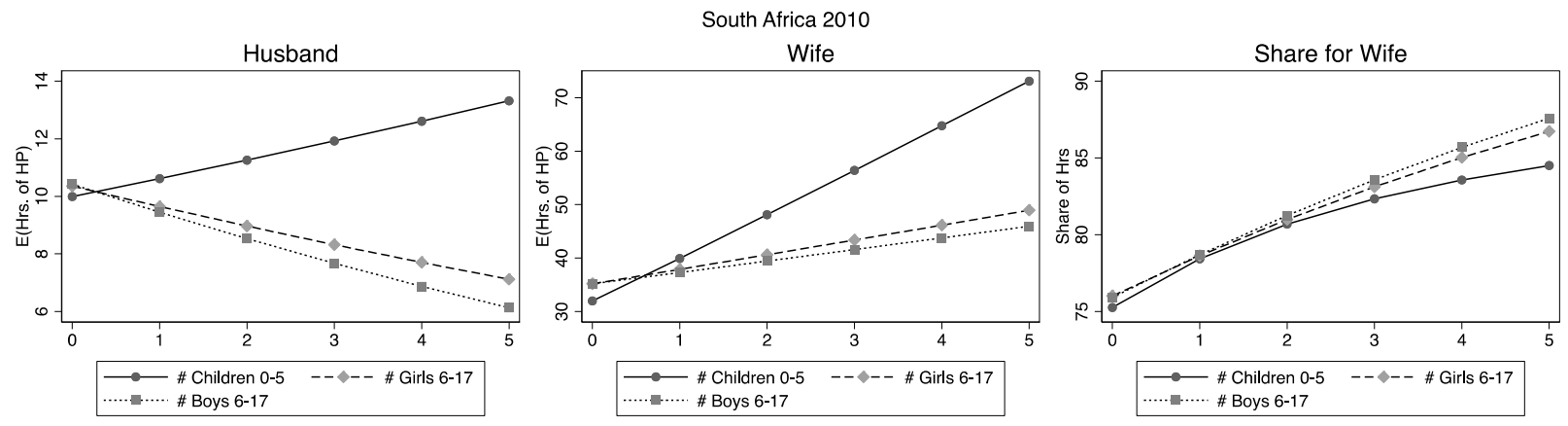

\subsection{Culture: Race and Religion}

An aspect that has been less explored in terms of intrahousehold time allocation is the role of culture. Culture is a qualitative and subjective concept, thus difficult to quantify and capture through measures. For our analysis, we consider two characteristics that we believe could be related to culture across African countries. These are religion (if they indicate to profess a Christian religion) and ethnicity (four major categories). We exclude Tanzania from the analysis, as neither variable is available for this country.

The influence of religion on women's gender role attitudes is well documented in the social science literature. For example, Voicu, Voicu, and Strapcova (2009) study religion's role on intrahousehold time allocation in Europe, indicating that religion provides a framework of gender roles in the households. They argue that Christian religious traditions encourage the gendered division of labor, reinforcing women's role as the main provider of housework.

We explore this possibility by including a binary variable to denote households who indicate that they follow a Christian religion (Protestant, Orthodox, or Catholic), using other religions (mostly Muslim) as the base group. The results suggest that households that indicate that they follow a Christian religion tend to be more equitable in terms of who is responsible for household production. In Christian households in Ethiopia, we estimate that women work 4.5 fewer hours per week, while in Ghana, men from Christian households dedicate 1.8 additional hours. Furthermore, religion seems to have a significant impact on reducing the share of hours for women in Ghana. 
For South Africa, we do not have access to information on religion. Instead, we know the ethnicity of the household (proxied by the husband's ethnicity) and some ethnicities are also closely tied to religion. From 2006 to 2015, South Africa's poverty rate decreased from 66.6 percent to 55.5 percent of the total population, but Black African's poverty rate is the only one that remains above the national level, 76.8 percent in 2006 and 64.2 percent in 2015. Although all ethnic groups observed a fall in their poverty rates, improvements were more prominent for Indians and Asians, whose poverty rate decreased from 20.9 percent in 2006 to 5.9 percent in 2015.

While we would expect the effects of ethnicity in South Africa to be similar across the two periods, we find staggering differences; therefore, we cannot discard the hypothesis that what we present next is the result of the interaction of the two effects: poverty and cultural value differences. In 2000, no significant differences were observed in hours of housework among all different ethnicities, providing only weak evidence that the wife's share of housework hours declines by 4.9 percentage points.

In 2010, however, we observe strong evidence that the ethnicity of the household matters for wives. In colored households, ${ }^{10}$ husbands seem to do an average of two more hours of housework per week, more than compensating for the decline in wives' expected hours per week (1.7 hours). In contrast, if the household ethnicity is Indian, the husband works 3.4 fewer hours per week, even though no additional time is observed among wives. Last but not least, in white households, husbands may work almost 3.7 more hours per week doing housework than Africans.

\footnotetext{
${ }^{10}$ The classification of colored households aims to identified how a person or household would have been classified under apartheid laws, an institutionalized system of segregation. Those classified as colored are usually descendants of two of different ethnicities.
} 
Table 9. Marginal Effects of Race and Religion

\begin{tabular}{|c|c|c|c|c|c|}
\hline & $\begin{array}{c}(1) \\
\text { Ethiopia } \\
\mathbf{2 0 1 3} \\
\end{array}$ & $\begin{array}{c}(2) \\
\text { Ghana } \\
2009 \\
\end{array}$ & $\begin{array}{c}(3) \\
\text { Tanzania } \\
2006 \\
\end{array}$ & $\begin{array}{c}(4) \\
\text { South Africa } \\
2000 \\
\end{array}$ & $\begin{array}{c}(5) \\
\text { South Africa } \\
\mathbf{2 0 1 0} \\
\end{array}$ \\
\hline \multicolumn{6}{|l|}{ Religion: Christian } \\
\hline Hrs of HP husband & $\begin{array}{l}-0.468 \\
(0.440)\end{array}$ & $\begin{array}{l}1.768^{* *} \\
(0.739)\end{array}$ & & & \\
\hline Hrs of HP wife & $\begin{array}{c}-4.466^{* * *} \\
(0.643)\end{array}$ & $\begin{array}{l}-0.931 \\
(1.776)\end{array}$ & & & \\
\hline Share of HHP wife & $\begin{array}{c}-0.930 \\
(0.659)\end{array}$ & $\begin{array}{c}-4.341^{* *} \\
(1.798)\end{array}$ & & & \\
\hline \multicolumn{6}{|l|}{ Base: African } \\
\hline Hrs of HP husband & & & & $8.980^{* * *}$ & $9.222^{* * *}$ \\
\hline Hrs of HP wife & & & & $34.314^{* * *}$ & $35.806^{* * *}$ \\
\hline Share of HHP wife & & & & $78.680^{* * *}$ & $78.302^{* * *}$ \\
\hline \multicolumn{6}{|l|}{ Colored } \\
\hline Hrs of HP husband & & & & $\begin{array}{l}-0.658 \\
(2.217)\end{array}$ & $\begin{array}{l}1.907^{* *} \\
(0.935)\end{array}$ \\
\hline Hrs of HP wife & & & & $\begin{array}{c}2.000 \\
(5.145)\end{array}$ & $\begin{array}{l}-1.559 \\
(1.474)\end{array}$ \\
\hline Share of HHP wife & & & & $\begin{array}{c}2.218 \\
(3.825) \\
\end{array}$ & $\begin{array}{l}-4.185^{* *} \\
(1.733) \\
\end{array}$ \\
\hline \multicolumn{6}{|l|}{ Indian } \\
\hline Hrs of HP husband & & & & $\begin{array}{c}1.232 \\
(1.128)\end{array}$ & $\begin{array}{c}-3.348^{* * *} \\
(1.232)\end{array}$ \\
\hline Hrs of HP wife & & & & $\begin{array}{c}0.002 \\
(1.951)\end{array}$ & $\begin{array}{c}0.709 \\
(3.028)\end{array}$ \\
\hline Share of HHP wife & & & & $\begin{array}{l}-2.227 \\
(2.193)\end{array}$ & $\begin{array}{l}6.785^{* * *} \\
(2.539)\end{array}$ \\
\hline \multicolumn{6}{|l|}{ White } \\
\hline Hrs of HP husband & & & & $\begin{array}{c}2.262 \\
(1.679)\end{array}$ & $\begin{array}{l}3.633^{* * *} \\
(1.230)\end{array}$ \\
\hline Hrs of HP wife & & & & $\begin{array}{c}-1.449 \\
(3.310)\end{array}$ & $\begin{array}{l}-0.377 \\
(2.011)\end{array}$ \\
\hline Share of HHP wife & & & & $\begin{array}{l}-4.897 \\
(3.235)\end{array}$ & $\begin{array}{c}-6.193^{* * *} \\
(1.936)\end{array}$ \\
\hline $\mathrm{N}$ & 9250 & 1037 & 1303 & 1294 & 2567 \\
\hline
\end{tabular}

\subsection{Basic Services and Household Amenities}

Turning our attention to aspects related to infrastructure, this section analyzes how access to certain amenities could affect the amount of time households dedicate to housework. For instance, having access to basic services that are close to the household has a direct impact on the time husbands and wives spend commuting to get basic resources, such as water and wood. We concentrate on three indicators, namely, if the household has access to a water source that is close to the house, if they use wood for cooking or heating, and if they use electricity as the main source of lighting or cooking. It is important to note that being in an urban or rural area is highly 
correlated with water access and the use of wood and electricity (see appendix D), therefore the results presented next might be influenced by the household's location.

In general, access to water close to the house produces a small and imprecise effect on hours of housework by the husband. In Ethiopia, we find the unexpected evidence that husbands and wives increase their engagement in housework by about 1.2 hours per week. In contrast, we observe the wives' hours decreasing in all other countries, although such decline is not significant (except for South Africa [2000]). The net effect seems to be a small decline in the wives' share of hours of work that is mostly not significant.

From a practical point of view, the use of wood as the primary source for heating and cooking should increase the amount of housework needed for maintaining this resource. In all countries, the gathering of wood and water falls under the responsibility of females, with 83.5 percent (Ethiopia) to 69 percent (Ghana) of water and 78 percent (Ghana) to 63.3 percent (South Africa [2010]) of wood fetched by females (see appendix D for details). Contrary to the expectations, using wood for cooking/heating does not seem to have a large impact on hours of household production. Based on the point estimates alone, it seems that it reduces the time wives spend on housework, without any compensation from their husbands. This puzzling result might reflect the high correlation of these variables among themselves and with urbanization.

The last amenity considered here is the use of electricity. Having access to electricity should, in principle, reduce the time spent on household production by allowing households to use more efficient means of meeting household needs (Costa et al. 2009; Wodon and Ying 2010). However, access to electricity could have the opposite effect by extending the length of the working day, especially if households do not have access to time-saving appliances. There is less certainty on whether the effect would be stronger for husbands compared to wives. The evidence in this case suggests that there is a reduction in overall hours of household production, but much of the time saved appears to be enjoyed by husbands. In Tanzania and South Africa, some decline in hours of housework by wives is observed, but the estimates are too imprecise to conclude. In aggregate, we observe a wider gap in the share of housework hours wives do in houses that use electricity. 
Table 10. Marginal Effects of Household Amenities

\begin{tabular}{|c|c|c|c|c|c|}
\hline & $\begin{array}{c}(1) \\
\text { Ethiopia } \\
\mathbf{2 0 1 3} \\
\end{array}$ & $\begin{array}{c}(2) \\
\text { Ghana } \\
2009 \\
\end{array}$ & $\begin{array}{c}(3) \\
\text { Tanzania } \\
\mathbf{2 0 0 6} \\
\end{array}$ & $\begin{array}{c}(4) \\
\text { South Africa } \\
2000\end{array}$ & $\begin{array}{c}(5) \\
\text { South Africa } \\
2010\end{array}$ \\
\hline \multicolumn{6}{|c|}{ Water access in or close to the house } \\
\hline Hrs of HP husband & $\begin{array}{l}1.228^{* *} \\
(0.518)\end{array}$ & $\begin{array}{c}1.296 \\
(0.948)\end{array}$ & $\begin{array}{l}-0.270 \\
(0.732)\end{array}$ & $\begin{array}{l}-0.645 \\
(1.023)\end{array}$ & $\begin{array}{c}0.132 \\
(0.921)\end{array}$ \\
\hline Hrs of HP wife & $\begin{array}{l}1.236^{*} \\
(0.746)\end{array}$ & $\begin{array}{l}-1.023 \\
(2.160)\end{array}$ & $\begin{array}{l}-1.532 \\
(1.211)\end{array}$ & $\begin{array}{l}-3.482^{* *} \\
(1.640)\end{array}$ & $\begin{array}{l}-1.886 \\
(1.506)\end{array}$ \\
\hline Share of HHP wife & $\begin{array}{l}-1.310^{*} \\
(0.766)\end{array}$ & $\begin{array}{l}-3.302 \\
(2.177)\end{array}$ & $\begin{array}{c}-0.155 \\
(1.355) \\
\end{array}$ & $\begin{array}{l}-0.796 \\
(1.938) \\
\end{array}$ & $\begin{array}{l}-1.238 \\
(1.831) \\
\end{array}$ \\
\hline \multicolumn{6}{|l|}{ Uses wood } \\
\hline Hrs of HP husband & $\begin{array}{c}-0.169 \\
(0.888)\end{array}$ & $\begin{array}{c}0.426 \\
(1.158)\end{array}$ & $\begin{array}{l}2.045^{* *} \\
(0.898)\end{array}$ & $\begin{array}{l}-0.389 \\
(1.437)\end{array}$ & $\begin{array}{c}0.267 \\
(1.044)\end{array}$ \\
\hline Hrs of HP wife & $\begin{array}{l}-2.217 \\
(1.353)\end{array}$ & $\begin{array}{c}2.155 \\
(2.541)\end{array}$ & $\begin{array}{l}-3.344^{* *} \\
(1.566)\end{array}$ & $\begin{array}{l}-1.194 \\
(2.517)\end{array}$ & $\begin{array}{l}-1.446 \\
(1.353)\end{array}$ \\
\hline Share of HHP wife & $\begin{array}{c}-0.535 \\
(1.344)\end{array}$ & $\begin{array}{l}-0.130 \\
(2.851)\end{array}$ & $\begin{array}{c}-4.846^{* * *} \\
(1.645)\end{array}$ & $\begin{array}{c}0.003 \\
(3.167)\end{array}$ & $\begin{array}{l}-1.285 \\
(1.946)\end{array}$ \\
\hline \multicolumn{6}{|l|}{ Uses electricity } \\
\hline Hrs of HP husband & $\begin{array}{c}-3.079^{* * *} \\
(0.843)\end{array}$ & $\begin{array}{l}-1.732 \\
(1.243)\end{array}$ & $\begin{array}{l}-1.726^{*} \\
(0.996)\end{array}$ & $\begin{array}{c}-0.645 \\
(1.375)\end{array}$ & $\begin{array}{l}-0.695 \\
(1.250)\end{array}$ \\
\hline Hrs of HP wife & $\begin{array}{c}0.000 \\
(1.461)\end{array}$ & $\begin{array}{c}0.471 \\
(2.136)\end{array}$ & $\begin{array}{l}-1.846 \\
(1.812)\end{array}$ & $\begin{array}{l}-2.169 \\
(2.028)\end{array}$ & $\begin{array}{l}-1.676 \\
(1.867)\end{array}$ \\
\hline Share of HHP wife & $\begin{array}{l}4.620^{* * *} \\
(1.340)\end{array}$ & $\begin{array}{l}4.041 \\
(2.919)\end{array}$ & $\begin{array}{c}2.413 \\
(1.951)\end{array}$ & $\begin{array}{l}-0.093 \\
(2.560)\end{array}$ & $\begin{array}{c}0.230 \\
(2.416)\end{array}$ \\
\hline \multicolumn{6}{|c|}{ House is a separate unit } \\
\hline Hrs of HP husband & & $\begin{array}{l}2.752^{*} \\
(1.572)\end{array}$ & & $\begin{array}{c}0.903 \\
(0.964)\end{array}$ & $\begin{array}{l}-1.839^{*} \\
(0.987)\end{array}$ \\
\hline Hrs of HP wife & & $\begin{array}{l}-3.019 \\
(2.176)\end{array}$ & & $\begin{array}{c}0.339 \\
(2.093)\end{array}$ & $\begin{array}{l}-1.121 \\
(1.299)\end{array}$ \\
\hline Share of HHP wife & & $\begin{array}{c}-7.454^{* *} \\
(3.522)\end{array}$ & & $\begin{array}{l}-1.441 \\
(2.029)\end{array}$ & $\begin{array}{c}2.404 \\
(1.527)\end{array}$ \\
\hline \multicolumn{6}{|c|}{ Lives close to public transportation } \\
\hline Hrs of HP husband & & & $\begin{array}{l}1.401^{* *} \\
(0.607)\end{array}$ & & \\
\hline Hrs of HP wife & & & $\begin{array}{c}1.824 \\
(1.109)\end{array}$ & & \\
\hline Share of HHP wife & & & $\begin{array}{l}-1.781 \\
(1.116)\end{array}$ & & \\
\hline $\mathrm{N}$ & 9250 & 1037 & 1303 & 1294 & 2567 \\
\hline
\end{tabular}

Note: Standard errors in parentheses; ${ }^{*} \mathrm{p}<0.1,{ }^{* *} \mathrm{p}<0.05,{ }^{* * *} \mathrm{p}<0.01$

According to Arku and Arku (2013), families living in self-contained houses, thus experiencing the greatest privacy, exhibit a more equitable distribution of housework and the highest rate of participation in housework by the husband. Support for this evidence is found only in Ghana. If the household is in a detached or semidetached house, the husband increases the number of hours of housework by 2.8 hours per week, whereas the wife reduces her hours by 3 hours per week. In 
South Africa, the evidence is mixed and suggests that husbands do less work when living in these conditions.

A final variable we consider, only for Tanzania, is if living close to public transportation has any impact on hours of household production. Having access to public transportation may reduce the time people spend commuting to work or commuting for procuring goods for the household. In the first case it may free some time that can be utilized in the household, and in the second may reduce the time on household production because less time is spent traveling. In the case of Tanzania, living close to public transportation seems to increase the time husbands (1.4 hours) and wives (1.8 hours) spend on housework per week. This improves the distribution of time between husband and wife.

\subsection{Urbanization, Income, and Wealth}

In this section, we explore other factors that are partially related to the household's income and wealth, as well as additional information that could be related to the wife's bargaining power. A variable that may capture a bulk of characteristics related to labor market health, job opportunities, and access to services is whether or not households live in urban areas. Because this variable captures a large set of idiosyncrasies across countries, our estimates also find large heterogeneity in its impact across countries. It is worth noticing that the urbanization rate is quite different across these countries. The percentage of households in our sample that are based in urban areas ranges from 16 percent in Ethiopia to 79 percent in South Africa (2010) (details are presented in table 3, in section 4.6). The estimations suggest that both husbands and wives in Ethiopia work fewer hours in urban areas compared to rural areas. However, because husbands' hours decrease more than wives', in relative terms, women's share of housework is larger in urban areas. In Tanzania, women in urban areas work five more hours per week; in Ghana, there seems to be no statistical difference in hours of housework in urban and rural areas.

The evidence for South Africa is also mixed. For 2000, the allocation of hours of work in urban areas was more equitable than in rural areas. In 2010, however, this trend is no longer observed, which could be explained by an unobserved change in characteristics across time, improvement in rural areas conditions that require fewer hours of work of wives, or a change in behavior, but 
we do not have enough information to support this. Furthermore, of all countries in our sample, South Africa shows the highest level of inequality and the poverty rate in rural areas is extremely high. Also, the change in the rural poverty rate might partially explain the variability of the results: 87.6 percent of the rural population in South Africa lived in poverty in 2006. This ratio fell to 77 percent by 2011 and was up again to 81.3 percent by 2015 (Statistics South Africa 2017).

Table 11. Marginal Effects of Other Factors

\begin{tabular}{|c|c|c|c|c|c|}
\hline & $\begin{array}{c}(1) \\
\text { Ethiopia } \\
2013\end{array}$ & $\begin{array}{c}(2) \\
\text { Ghana } \\
2009\end{array}$ & $\begin{array}{c}(3) \\
\text { Tanzania } \\
\mathbf{2 0 0 6}\end{array}$ & $\begin{array}{c}(4) \\
\text { South } \\
\text { Africa } \\
\mathbf{2 0 0 0}\end{array}$ & $\begin{array}{c}(5) \\
\text { South } \\
\text { Africa } \\
\mathbf{2 0 1 0}\end{array}$ \\
\hline \multicolumn{6}{|l|}{ Urban area } \\
\hline \multirow{2}{*}{$\begin{array}{l}\text { Hrs of HP } \\
\text { husband }\end{array}$} & $-2.797^{* * *}$ & -0.356 & 0.372 & $2.096^{*}$ & 1.139 \\
\hline & (1.030) & (1.009) & $(0.998)$ & (1.188) & $(0.800)$ \\
\hline \multirow[t]{2}{*}{ Hrs of HP wife } & $-5.369^{* * * *}$ & -0.409 & $4.807^{* * *}$ & $-3.652^{*}$ & 0.203 \\
\hline & (1.574) & $(2.513)$ & (1.700) & (2.077) & $(1.276)$ \\
\hline \multirow{2}{*}{$\begin{array}{l}\text { Share of HHP } \\
\text { wife }\end{array}$} & 2.364 & 0.646 & 1.217 & $-5.720^{* *}$ & -1.844 \\
\hline & $(1.718)$ & $(2.353)$ & $(1.693)$ & $(2.342)$ & $(1.483)$ \\
\hline \multicolumn{6}{|l|}{$\begin{array}{l}\text { Consumption: } \\
\text { Based } \\
\text { category } \\
\text { (lowest) }\end{array}$} \\
\hline \multicolumn{6}{|l|}{ husband } \\
\hline Hrs of HP wife & $43.852^{* * *}$ & $35.169^{* * *}$ & $39.331^{\text {*** }}$ & $36.375^{* * *}$ & $35.447^{* * *}$ \\
\hline $\begin{array}{l}\text { Share of HHP } \\
\text { wife }\end{array}$ & $79.111^{* * *}$ & $88.087^{* * *}$ & $81.930^{* * *}$ & $73.891^{* * *}$ & $77.491^{* * *}$ \\
\hline \multicolumn{6}{|l|}{$\begin{array}{l}\text { Consumption } \\
\text { group } 2\end{array}$} \\
\hline \multirow{2}{*}{$\begin{array}{l}\text { Hrs of HP } \\
\text { husband }\end{array}$} & $-1.198^{* *}$ & 1.118 & -0.355 & $-2.723^{* *}$ & $1.462^{*}$ \\
\hline & $(0.476)$ & $(0.845)$ & $(0.550)$ & $(1.258)$ & $(0.849)$ \\
\hline \multirow[t]{2}{*}{ Hrs of HP wife } & $1.177^{*}$ & $-2.774^{*}$ & -1.241 & $-3.380^{*}$ & 1.003 \\
\hline & $(0.663)$ & (1.636) & $(0.991)$ & (1.779) & (1.336) \\
\hline \multirow{2}{*}{$\begin{array}{l}\text { Share of HHP } \\
\text { wife }\end{array}$} & $2.166^{* * *}$ & $-3.487^{*}$ & 0.134 & 2.540 & -1.898 \\
\hline & $(0.710)$ & $(1.960)$ & $(1.021)$ & $(2.139)$ & $(1.579)$ \\
\hline \multicolumn{6}{|l|}{$\begin{array}{l}\text { Consumption } \\
\text { group } 3\end{array}$} \\
\hline \multirow{2}{*}{$\begin{array}{l}\text { Hrs of HP } \\
\text { husband }\end{array}$} & -0.696 & 0.196 & 1.280 & -0.968 & 1.239 \\
\hline & $(0.632)$ & $(0.977)$ & $(0.960)$ & $(1.832)$ & (1.083) \\
\hline Hrs of HP wife & 0.972 & $-3.818^{*}$ & $-2.513^{*}$ & -0.343 & 0.156 \\
\hline \multirow{2}{*}{$\begin{array}{l}\text { Share of HHP } \\
\text { wife }\end{array}$} & $\begin{array}{c}(0.896) \\
1.363\end{array}$ & $\begin{array}{l}(2.253) \\
-1.805\end{array}$ & $\begin{array}{l}(1.434) \\
-3.295^{*}\end{array}$ & $\begin{array}{c}(2.318) \\
1.309\end{array}$ & $\begin{array}{l}(1.712) \\
-2.010\end{array}$ \\
\hline & $(0.933)$ & (2.309) & $(1.763)$ & (3.013) & (2.000) \\
\hline
\end{tabular}




\begin{tabular}{|c|c|c|c|c|c|}
\hline \multicolumn{6}{|l|}{ Consumption } \\
\hline \multirow{2}{*}{$\begin{array}{l}\text { Hrs of HP } \\
\text { husband }\end{array}$} & -0.608 & 0.197 & 1.772 & $-6.072^{* * *}$ & 0.209 \\
\hline & $(1.066)$ & $(1.249)$ & $(1.282)$ & $(2.113)$ & $(1.430)$ \\
\hline \multirow[t]{2}{*}{ Hrs of HP wife } & 2.367 & -1.272 & 0.010 & $-5.457^{*}$ & -0.746 \\
\hline & $(1.747)$ & (3.092) & $(2.077)$ & $(3.205)$ & $(2.361)$ \\
\hline \multirow{2}{*}{$\begin{array}{l}\text { Share of HHP } \\
\text { wife }\end{array}$} & 1.724 & -0.857 & -2.956 & $8.053^{* *}$ & -0.777 \\
\hline & $(1.606)$ & $(3.025)$ & $(2.102)$ & $(3.773)$ & $(2.668)$ \\
\hline \multicolumn{6}{|l|}{$\begin{array}{l}\text { Consumption: } \\
\text { NA }\end{array}$} \\
\hline \multirow{2}{*}{$\begin{array}{l}\text { Hrs of HP } \\
\text { husband }\end{array}$} & & & & -1.479 & -0.661 \\
\hline & & & & $(2.309)$ & $(1.529)$ \\
\hline \multirow[t]{2}{*}{ Hrs of HP wife } & & & & $-5.267^{* *}$ & 0.445 \\
\hline & & & & $(2.611)$ & $(2.129)$ \\
\hline \multirow{2}{*}{$\begin{array}{l}\text { Share of HHP } \\
\text { wife }\end{array}$} & & & & -0.849 & 1.401 \\
\hline & & & & $(4.110)$ & $(2.651)$ \\
\hline \multicolumn{6}{|c|}{ Share of assets controlled by women } \\
\hline \multirow{2}{*}{$\begin{array}{l}\text { Hrs of HP } \\
\text { husband }\end{array}$} & 0.010 & 0.010 & & & \\
\hline & $(0.011)$ & $(0.014)$ & & & \\
\hline \multirow[t]{2}{*}{ Hrs of HP wife } & 0.014 & -0.030 & & & \\
\hline & $(0.015)$ & $(0.032)$ & & & \\
\hline \multirow{2}{*}{$\begin{array}{l}\text { Share of HHP } \\
\text { wife }\end{array}$} & -0.009 & -0.035 & & & \\
\hline & $(0.017)$ & $(0.033)$ & & & \\
\hline \multicolumn{6}{|c|}{$\begin{array}{l}\text { Share of expenditures controlled by } \\
\text { women }\end{array}$} \\
\hline \multirow{2}{*}{$\begin{array}{l}\text { Hrs of HP } \\
\text { husband }\end{array}$} & -0.014 & $-0.062^{* * *}$ & & & \\
\hline & $(0.011)$ & $(0.023)$ & & & \\
\hline Hrs of HP wife & -0.004 & $\begin{array}{l}-0.067 \\
(0.044)\end{array}$ & & & \\
\hline \multirow{2}{*}{$\begin{array}{l}\text { Share of HHP } \\
\text { wife }\end{array}$} & 0.019 & $0.113^{* *}$ & & & \\
\hline & $(0.017)$ & $(0.050)$ & & & \\
\hline \multicolumn{6}{|c|}{ Percentile wealth index } \\
\hline \multirow{4}{*}{$\begin{array}{l}\text { Hrs of HP } \\
\text { husband } \\
\text { Hrs of HP wife }\end{array}$} & -0.008 & 0.011 & -0.013 & $0.054^{*}$ & 0.018 \\
\hline & $(0.009)$ & $(0.021)$ & $(0.012)$ & $(0.030)$ & $(0.020)$ \\
\hline & $-0.040^{* * *}$ & -0.033 & -0.007 & 0.004 & $-0.064^{*}$ \\
\hline & $(0.013)$ & $(0.039)$ & $(0.022)$ & $(0.056)$ & $(0.034)$ \\
\hline \multirow{2}{*}{$\begin{array}{l}\text { Share of HHP } \\
\text { wife }\end{array}$} & -0.003 & -0.042 & 0.019 & -0.088 & $-0.072^{* *}$ \\
\hline & $(0.013)$ & $(0.051)$ & $(0.021)$ & $(0.057)$ & $(0.035)$ \\
\hline $\mathrm{N}$ & 9250 & 1037 & 1303 & 1294 & 2567 \\
\hline
\end{tabular}


The next aspect we consider is the role of wealth as measured by consumption levels. Because this data is available in different formats across countries, we reclassify them into four consumption levels from lowest to highest, but should not be directly compared across countries. Households with higher income/consumption levels may be able to purchase services and goods that may help women reduce the time they have to spend doing housework. If this is the case, we will observe households in higher consumption groups spending less time on housework.

Based on our estimations, there is not enough evidence to suggest household income has this type of impact on household production. The estimations for Ethiopia and South Africa (2010) show no specific trend on reduced hours of work of husbands nor wives, with most estimations indicating that differences across consumption levels are not statistically significant when compared to the poorest households. In Tanzania, we do observe some reduction in hours of housework done by wives, but the effect is not consistent for households with the highest level of consumption. In Ghana and South Africa (2000) the trend is somewhat stronger, indicating that women living in households with higher consumption levels engage in less housework. In South Africa (2000), however, we observe the unexpected result that men reduce their hours of work even more than women do for households with the highest consumption levels.

Because its wealth level could better capture household wellbeing, we also use a wealth index constructed based on a principal component analysis as a control (see appendix $\mathrm{C}$ for details). The index has been normalized and represents the relative position the household has with respect to the weighted index distribution within the sample.

The estimated marginal effects suggests that wealth is correlated with fewer hours of housework for the wife and in South Africa (2000) also an increase in the number of husbands' hours. While some results are statistically significant, they are all relatively small in magnitude. Using the predicted number of hours of work presented in figure 4 , we can visualize the relationship between wealth and hours of housework. 
Except for South Africa (2010), the husbands' predicted expected hours curve is mostly flat with respect to the wealth index. For wives, however, the effect is somewhat more consistent, with a stronger decline in hours of work in Ethiopia, Ghana, and South Africa (2010). Even in these countries, however, the predicted decline ranges between 4 hours to 6 hours per week when comparing the richest and poorest countries. This translates into a small decline in the share of hours of work by women.

Figure 4. Average Expected Hours of Household Production per Week by Wealth Rank
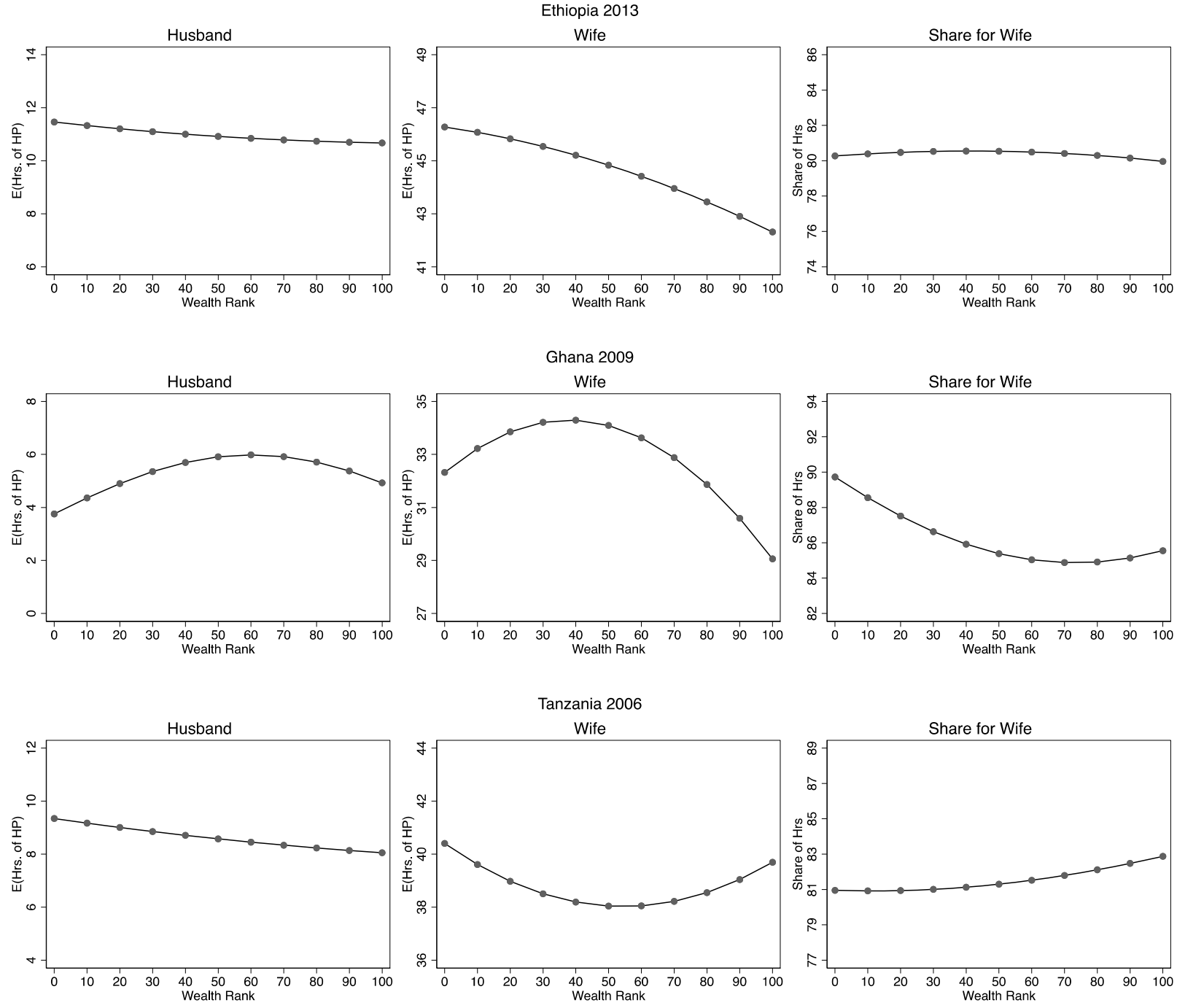

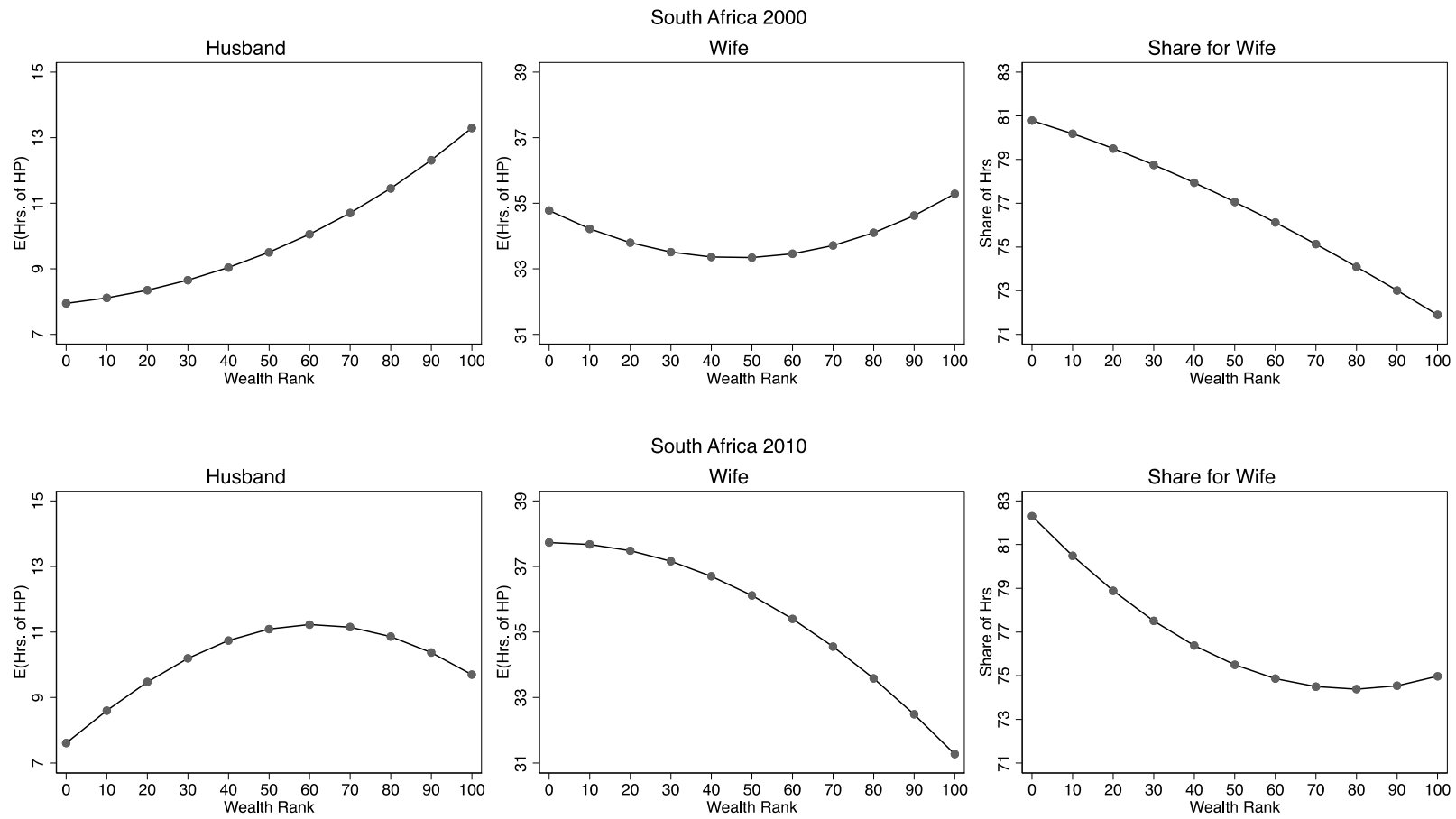

\subsection{Substitutes or Complements?}

To close the discussion regarding the allocation of time within the household we analyze two alternative assumptions regarding husbands' and wives' household production time, i.e., that the time spent by one individual can be reduced by an increase in the time spent their spouse spends or that their time complements each other and therefore when one individual increases their hours their partner does as well.

Assuming that a household's needs, in terms of required hours of household production and adjusted by family size, are fixed across households, one may expect husbands and wives to function as substitutes, with one spouse's hours decreasing as the other's increases. The empirical evidence, however, seems to suggest that spouses are more like complements, with both increasing their hours of housework simultaneously (Bredtmann 2014; Hamermesh 2002; Jenkins and Osberg 2005).

In the summary statistics and contour plots, we show that for most countries in our sample there was a small but positive correlation between husbands' and wives' hours of household production (naïve correlation). Correcting this estimation for the censored nature of the data, we can also 
estimate the unconditional correlation between the latent hours of housework using the bivariate Tobit model without explanatory variables. As can be seen in table 12, the correlation between hours of work remains mostly positive and statistically significant for the censored data. Even in South Africa, which exhibits the lowest correlations, the evidence suggests that a husband's and wife's hours are not substitutes but rather complements.

A drawback of using the simple correlation measure is that it may also capture other confounding factors. For example, because husbands and wives do more hours of household production in larger families, the unconditional correlation may be positive. Using our main model specification, we reestimate what we call "conditional correlation" after other factors have been accounted for.

The results suggest that controlling for other factors reduces the previously observed positive correlation between husbands' and wives' hours of housework, but only in Ghana. We do not observe large changes in other countries, and in South Africa the correlation increases.

Table 12. Naïve, Unconditional, and Conditional Correlation of Hours of HP

\begin{tabular}{lccccc}
\hline & $\begin{array}{c}(1) \\
\text { Ethiopia } \\
2013\end{array}$ & $\begin{array}{c}(2) \\
\text { Ghana } \\
2009\end{array}$ & $\begin{array}{c}(3) \\
\text { Tanzania } \\
2006\end{array}$ & $\begin{array}{c}(4) \\
\text { South Africa } \\
2000\end{array}$ & $\begin{array}{c}(5) \\
\text { South Africa } \\
2010\end{array}$ \\
\hline Naïve rho & 0.128 & 0.063 & 0.132 & 0.029 & -0.004 \\
\hline $\begin{array}{l}\text { Without controls } \\
\text { rho:_cons }\end{array}$ & $\begin{array}{c}0.152^{* * *} \\
(0.015)\end{array}$ & $\begin{array}{c}0.104^{*} \\
(0.055)\end{array}$ & $\begin{array}{c}0.147^{* * *} \\
(0.032)\end{array}$ & $\begin{array}{c}0.053 \\
(0.061)\end{array}$ & $\begin{array}{c}-0.024 \\
(0.036)\end{array}$ \\
\hline $\begin{array}{c}\text { With controls } \\
\text { rho:_cons }\end{array}$ & $\begin{array}{c}0.120^{* * *} \\
(0.015)\end{array}$ & $\begin{array}{c}0.0341 \\
(0.053)\end{array}$ & $\begin{array}{c}0.162^{* * *} \\
(0.032)\end{array}$ & $\begin{array}{c}0.074 \\
(0.049)\end{array}$ & $\begin{array}{c}0.071^{* *} \\
(0.036)\end{array}$ \\
\hline $\mathrm{N}$ & 9250 & 1037 & 1303 & 1294 & 2567 \\
\hline
\end{tabular}

Notes: Standard errors in parentheses; ${ }^{*} \mathrm{p}<0.1,{ }^{* *} \mathrm{p}<0.05,{ }^{* * *} \mathrm{p}<0.01$

One option that may explain this phenomenon but cannot be formally modeled in the framework of our econometric strategy is to differentiate spouses' hours of work between activities they do jointly versus activities they do on their own. As Bredtmann (2014), Hamermesh (2002), and Jenkins and Osberg (2005) state, couples may tend to synchronize their activities of leisure and work because they draw utility by doing activities together. For this analysis, we consider that spouses do housework "jointly" if they engage in any type of household production activities (care, core, or procurement) the same day and in the same time slot. Because of this restriction, 
we exclude data where the husband and wife were not interviewed the same day. Table 13 provides summary statistics of these results.

Two important differences should be noted from this exercise. Almost half of the housework done by husbands is done at the same time as their wives, with only a small fraction of wives' time being shared. In this case, we also observed that its correlation with alone time across all countries is negative. This suggests that husbands' and wives' housework seem to be complements because husbands synchronize the majority of their activities with their wives. However, when looking at the time they do on their own, the correlation between husbands' and wives' hours of work is negative, suggesting that some degree of substitutability exists. Therefore, increases in hours that husbands contribute alone could help decrease the hours of work done by wives. Some further study is necessary to determine what contributes to increases in husbands' alone hours instead of their shared time.

Table 13. Hours of Work: Together versus Alone

\begin{tabular}{lrrrrr}
\hline & $\begin{array}{c}\text { Ethiopia } \\
\mathbf{2 0 1 3}\end{array}$ & $\begin{array}{c}\text { Ghana } \\
\text { 2009 }\end{array}$ & $\begin{array}{c}\text { Tanzania } \\
\mathbf{2 0 0 6}\end{array}$ & $\begin{array}{c}\text { South Africa } \\
\text { 2000 }\end{array}$ & $\begin{array}{c}\text { South Africa } \\
\mathbf{2 0 1 0}\end{array}$ \\
\hline Husband hrs of HP & 10.47 & 5.01 & 7.94 & 9.16 & 9.78 \\
\%alone & 50.0 & 61.4 & 52.7 & 52.9 & 55.1 \\
\%together & 50.0 & 38.6 & 47.3 & 47.1 & 44.9 \\
Wife hrs of HP & 44.60 & 33.24 & 38.83 & 34.32 & 35.97 \\
\%alone & 88.3 & 94.2 & 77.7 & 87.4 & 87.8 \\
\%together & 11.7 & 5.8 & 22.3 & 12.6 & 12.2 \\
Corr. alone time & -0.240 & -0.195 & -0.255 & -0.294 & -0.348 \\
\hline
\end{tabular}

\section{DISCUSSION AND CONCLUSIONS}

This paper analyzes how household and personal characteristics determine the allocation of time between husbands and wives in nuclear families in Ethiopia, Ghana, South Africa, and Tanzania. We have used data from time use surveys from all four countries, including data for two different years for South Africa. We can observe from our sample that across all countries, wives contribute the overwhelming majority of the time dedicated to household production. On average, wives' housework time range from 44.6 hours per week (Ethiopia) to 32.69 hours per 
week (Ghana), while husbands' average contribution ranges from 10.5 hours per week (Ethiopia) to 4.9 hours per week (Ghana).

To evaluate what determines this unequal distribution we have built a bivariate Tobit model and calculated the marginal effect of a set of characteristics describing the household and its members. The variability of results across the countries creates an obstacle to drawing any general conclusions, though a few consistent results can be highlighted.

Our model predicts that women that engaged in paid employment dedicate fewer hours to household production while unemployed women dedicate more hours than their self-employed counterparts. This can be evidence for the time availability theory since women might reduce their housework give stricter constraints on their time. It can also be interpreted as indicating that bargaining power plays a role in defining the division of household production between husbands and wives; this is somewhat supported by the positive impact that wives paid employment has on husbands' hours, although it is only significant for Ethiopia and Ghana.

Furthermore, there is evidence that factors that impact the overall hours necessary to fulfill the household needs, such as the presence of young children, increase wives' hours more than their husbands'. While in the case of time-saving characteristics, such as the use of electricity, husbands are the ones to collect the benefits and observe a greater decrease in hours. Therefore, this work also provides some evidence of the gender ideology theory.

Finally, to draw policy conclusions from our work it would be important to tackle the question of complementarity and substitutability of household production between husbands' and wives' time. The fact that around half of the time that husbands contribute to household production are spent in activities done simultaneously with their wives leads to the necessity to further explore which factors could lead to an increase of hours that husbands dedicate to household production alone, otherwise efforts in increasing husbands' contributions might come at the cost of even higher demands on their wives. 


\section{REFERENCES}

Adesina, J. O. 2016. "Inequality in sub-Saharan Africa: dimensions and drivers." In World Social Science Report 2016: Challenging Inequalities: Pathways to a Just World. Paris: United Nations Educational, Scientific and Cultural Organization (UNESCO).

Amporfu, E., P. E. Frimpong, D., Sakyi, E. Arthur, and J. Novignon. 2018. “The Distribution of Housework among men and women in Ghana: The National Time Transfer Accounts Approach.” Counting Women's Work Ghana Working Paper 3. Cape Town: University of Cape Town.

Arku, F. S. 2010. “Time savings from easy access to clean water: Implications for rural men's and women's well-being." Progress in Development Studies 103: 233-46.

Arku, F. S., and C. Arku. 2013. "What has Housing Structure got to do with it? Men's Involvement in Housework within different Housing Structures in Peri-Urban Communities in Ghana." European Journal of Social Sciences 363: 307-15.

Arora, D. 2015. “Gender differences in time-poverty in rural Mozambique.” Review of Social Economy 73(2): 196-221.

Bianchi, S. M. 2000. "Maternal employment and time with children: Dramatic change or surprising continuity?" Demography 37(4): 401-14.

Bredtmann, J. 2014. "The Intra-household Division of Labor: An Empirical Analysis of Spousal Influences on Individual Time Allocation.” Labour 28(1): 1-39.

Brines, J. 1994. "Economic dependency, gender, and the division of labor at home." American Journal of Sociology 100(3): 652-88.

Charmes, J. 2006. “A review of empirical evidence on time use in Africa from UN-sponsored surveys." In C. M. Blackden and Q. Wodon (eds.) Gender, time use, and poverty in subSaharan Africa. Washington, DC: The World Bank.

Costa, J., D. Hailu, E. Silva, and R. Tsukada, 2009. "The implications of water and electricity supply for the time allocation of women in rural Ghana." International Policy Centre for Inclusive Growth Working Paper No. 59: Brasília: International Policy Centre for Inclusive Growth.

Duflo, E., and C. Udry. 2003. "Intrahousehold resource allocation in Côte d'Ivoire: Social norms, separate accounts and consumption choices." Economic Growth Center Discussion Paper No. 857. New Haven, CT: Economic Growth Center, Yale University.

Duflo, E. 2003 “Grandmothers and granddaughters: Old age pension and intra-household allocation in South Africa." World Bank Economic Review 17(1): 1-25. 
Evertsson, M., and M. Nermo. 2004. "Dependence within Families and the Division of Labor: Comparing Sweden and the United States." Journal of Marriage and Family 66(5): $1272-86$.

Feinstein, S., R. Feinstein, and S. Sabrow. 2010. "Gender inequality in the division of household labour in Tanzania." African Sociological Review/Revue Africaine de Sociologie 14(2): 98-109.

Ferrant, G., and A. Thim. 2019. "Measuring women's economic empowerment: Time use data and gender inequality." OECD Development Policy Papers No. 16. Paris: Organisation for Economic Co-operation and Development (OECD)

Floro, M. S., and H. Komatsu. 2011. "Gender and work in South Africa: what can time-use data reveal?" Feminist Economics 17(4): 33-66.

Fontana, M., and L. Natali. 2008. "Gendered patterns of time use in Tanzania: public investment in infrastructure can help." IFPRI project on "Evaluating the Long-Term Impact of Gender-focused Policy Interventions" New York: International Food Policy Research Institute (IFPRI).

Fortin, B. and G. Lacroix, 1997. "A test of the unitary and collective models of household labour supply.” The Economic Journal 107(443): 933-55.

Geist, C., and L. Ruppanner. 2018. "Mission impossible? New housework theories for changing families." Journal of Family Theory \& Review 10: 242-62.

Getahun, C. 2018. "Resources, Time, and Gender: Determinants of Women's Housework in Bahir Dar and nearby Rural Villages, Northwest Ethiopia." Ethiopian Journal of the Social Sciences and Humanities 14(2).

Ghana Statistical Service. 2018. "Ghana Living Standards Survey Round 7 GLSS7.” Accra: Ghana Statistical Service.

Gough, M., and A. Killewald. 2010. "Gender, job loss, and housework: The time availability hypothesis revisited.” PSC Research Report No. 10-710. Ann Arbor: Population Studies Center.

- 2011. "Unemployment in families: The case of housework." Journal of Marriage and Family 73(5):1085-100.

Gupta, S. 2006. "Her money, her time: Women's earnings and their housework hours." Social Science Research 35(4): 399-417.

Hamermesh, D. S. 2002. “Timing, Togetherness and Time Windfalls.” Journal of Population Economics 15(4): 601-23. 
Heim, B. T. 2009. "Structural Estimation of Family Labor Supply with Taxes: Estimating a Continuous Hours Model Using a Direct Utility Specification.” Journal of Human Resources 44 (2): 350-85.

Herrera, J., and C. Torelli. 2013. "Domestic Work and Employment in Africa: What Is the Trade-Off for Women?” In P. De Vreyer and F. Roubaud (eds.), Urban Labor Markets in Sub-Saharan Africa. Washington, DC: The World Bank and Agence Française de Développement.

Hotchkiss, L., R. E. Moore, and F. Rios-Avila. 2012. "Assessing the Welfare Impact of Tax Reform: A Case Study of the 2001 U.S. Tax Cut." Review of Income and Wealth 58(2): $233-56$.

Jenkins, S. P., and L. Osberg. 2005. "Nobody to Play with? The Implications of Leisure Coordination." In D. S. Hamermesh and G. A. Pfann (eds.), The Economics of Time Use. Amsterdam: Elsevier.

Killewald, A., and M. Gough. 2010. 'Money isn't everything: Wives' earnings and housework time.” Social Science Research 39(6): 987-1003.

Lachance-Grzela, M., and G. Bouchard. 2010. "Why do women do the lions share of housework? A decade of research." Sex Roles 63(11-12): 767-80.

Lawson, D. 2008. "Infrastructure and time poverty in Lesotho." South African Journal of Economics 76(1): 77-88.

Lundberg, S., and R. A. Pollak, 1996. "Bargaining and distribution in marriage." Journal of Economic Perspectives 10(4): 139-58.

Lundberg, S. J., R. A. Pollak, and T. J. Wales. 1997. "Do husbands and wives pool their resources? Evidence from the United Kingdom child benefit." Journal of Human Resources 32(3): 463-80.

Milanovic, B. 2003. "Is inequality in Africa really different?" World Bank Policy Research Working Paper No. 3169. Washington, DC: The World Bank.

Mitik, L., and B. Decaluwé. 2009. "Market Labor, Household Work, and Schooling in South Africa: Modeling the Effects of Trade on Adults' and Children's Time Allocation." Children Youth and Environments 19(2): 83-110.

National Planning Commission. 2017. "Ethiopia's Progress Towards Eradicating Poverty: An Interim Report on 2015/16 Poverty Analysis Study." Addis Ababa: United Nations Development Programme (UNDP). 
Ndlovu, P., S. Mohapatra, and M. Luckert. 2018. "Income Effects on Intra-Household Time Allocation: Regression Discontinuity Evidence." Journal of International Development 30(4): 713-19.

Oosthuizen, M. 2018. “Counting women's work in South Africa: Incorporating unpaid work into estimates of the Economic Lifecycle in 2010." Counting Women's Work Ghana Working Paper No. 8. Cape Town: University of Cape Town.

Pollak, R. A. 2005. "Bargaining power in marriage: Earnings, wage rates and household production.” NBER Working Paper No.11239. Cambridge, MA: National Bureau of Economic Research (NBER).

Rangel, M. A. 2006. “Alimony rights and intrahousehold allocation of resources: evidence from Brazil.” The Economic Journal 116(513): 627-58.

Ransom, M. R. 1987. "An Empirical Model of Discrete and Continuous Choice in Family Labor Supply." The Review of Economics and Statistics, 69(3): 465-72.

Rios-Avila, F. 2020. "MBITOBIT: Stata module to fit bivariate Tobit regression. Statistical Software Components S458741.” Boston College Department of Economics, revised May 10, 2020.

Robles, P. S. 2010. "Gender disparities in time allocation, time poverty, and labor allocation across employment sectors in Ethiopia.” In J. Saba Arbache, A. Kolev, and E. Fillipiak (eds.), Gender Disparities in Africa's Labor Market. Washington, DC: Agence Française de Développement and the World Bank

Sawo, M. 2020. "Time and Consumption Poverty among Mainland Tanzanian Children: Material Conditions to Secure Stated Rights." Graduate Programs in Economic Theory and Policy Thesis No. 23. Available at: https://digitalcommons.bard.edu/levy_ms/23

Shelton, B. A., and D. John. 1996. "The Division of Household Labor.” Annual Review of Sociology 22: 299-322.

Simister, J. 2013. “Is Men's Share of Housework Reduced by 'Gender Deviance Neutralization'? Evidence From Seven Countries.” Journal of Comparative Family Studies 44(3): 311-25.

Statistics South Africa. 2017. "Poverty trends in South Africa: An examination of absolute poverty between 2006 and 2015." Press release, August 22. Pretoria: Statistics South Africa.

Tanzania National Bureau of Statistics. 2019. "Household budget survey 2017/18." Dodoma, Tanzania: Tanzania National Bureau of Statistics. 
Vella, F. 2004. "Gender Roles and Human Capital Investment: The Relationship between Traditional Attitudes and Female Labour Market Performance." Economica 61(242): 191-211.

Voicu, M., B. Voicu, and K. Strapcova. 2009. "Housework and gender inequality in European countries.” European Sociological Review 25(3): 365-77.

Wodon, Q., and Y. Ying. 2010. "Domestic work time in Sierra Leone.” In J. Saba Arbache, A. Kolev, and E. Fillipiak (eds.), Gender Disparities in Africa's Labor Market. Washington, DC: Agence Française de Développement and the World Bank.

Zacharias, A., T. Masterson, F. Rios-Avila, K. Kim, and T. Khitarishvili. 2018. "The Measurement of Time and Consumption Poverty in Ghana and Tanzania." Research Project Report, August. Annandale-on-Hudson, NY: Levy Economics Institute of Bard College.

Zuo, J., and Y. Bian. 2001. "Gendered resources, division of housework, and perceived fairness. A case in urban China." Journal of Marriage and Family 63(4): 1122-33. 


\section{APPENDIX A: VARIABLES IN THE ESTIMATION}

As stated in section 3, the model estimated in this paper assumes that the hours of household production by a husband and wife are functions of their characteristics, their partners, and household characteristics

$$
\begin{aligned}
& h_{i, h}^{*}=g_{h}\left(h_{i, w}^{*}, X_{i}\right) \\
& h_{i, w}^{*}=g_{w}\left(h_{i, h}^{*}, X_{i}\right)
\end{aligned}
$$

where $h_{i, h}^{*}$ and $h_{i, w}^{*}$ are the number of desired hours of household work and $X_{i}$, is a vector of characteristics of the husband, the wife, and the household.

In this appendix, we describe the variables used in $X_{i}$. Summary statistics for the variables are presented in section 4.6. There is some variability in the specification according to data availability.

For all of the countries in our study, the vector $X_{i}$ includes age, level of education, and employment status. The vector $X_{i}$ also includes the number of children that are under 6 years old, number of boys between 6 and 17 years of age, number of girls between 6 and 17 years of age, wealth index (see appendix C), percent of the population in each of the four consumption groups, and four dummies. The first dummy assumes the value of one if the household is located in an urban area; the second dummy is set to be one if the main source of water is inside or close to the house. Finally, the last two dummies are equal to one if the household uses wood and uses electricity, respectively.

Additionally, we control for whether the house is a detached or semidetached unit (for the case of Ghana and South Africa). For Tanzania, we control for whether or not the household is 30 minutes or less from the closest public transportation. For Ethiopia and Ghana, we add the share of assets and spending that are controlled by women and a dummy for whether or not the husband is Christian as a proxy for household religion. Finally, for South Africa, we add a 
variable for race. A summary of the variables that are used for each country is presented in table A.1.

Table A.1 Variables Used by Country

\begin{tabular}{|c|c|c|c|c|c|}
\hline & $\begin{array}{c}\text { Ethiopia } \\
2013\end{array}$ & $\begin{array}{c}\text { Ghana } \\
2009\end{array}$ & $\begin{array}{c}\text { Tanzania } \\
2006 \\
\end{array}$ & $\begin{array}{c}\text { South Africa } \\
2000 \\
\end{array}$ & $\begin{array}{c}\text { South Africa } \\
2010 \\
\end{array}$ \\
\hline \multicolumn{6}{|l|}{$\begin{array}{l}\text { Husband and wife } \\
\text { characteristics }\end{array}$} \\
\hline Age & $\mathrm{x}$ & $\mathrm{x}$ & $\mathrm{x}$ & $\mathrm{x}$ & $\mathrm{x}$ \\
\hline $\begin{array}{l}\text { Education (fours groups, } \\
\text { preschool or no education is } \\
\text { base }\end{array}$ & $\mathrm{x}$ & $\mathrm{x}$ & $\mathrm{x}$ & $\mathrm{x}$ & $\mathrm{x}$ \\
\hline $\begin{array}{l}\text { Employment (three groups, self } \\
\text { employed is base) }\end{array}$ & $\mathrm{x}$ & $\mathrm{x}$ & $\mathrm{x}$ & $\mathrm{x}$ & $\mathrm{x}$ \\
\hline \multicolumn{6}{|l|}{ Household characteristics } \\
\hline Number of children aged $0-5$ & $\mathrm{x}$ & $\mathrm{x}$ & $\mathrm{x}$ & $\mathrm{x}$ & $\mathrm{x}$ \\
\hline Number of boys $6-17$ & $\mathrm{x}$ & $\mathrm{x}$ & $\mathrm{x}$ & $\mathrm{x}$ & $\mathrm{x}$ \\
\hline Number of girls 6-17 & $\mathrm{x}$ & $\mathrm{x}$ & $\mathrm{x}$ & $\mathrm{x}$ & $\mathrm{x}$ \\
\hline Wealth index & $\mathrm{x}$ & $\mathrm{x}$ & $\mathrm{x}$ & $\mathrm{x}$ & $\mathrm{x}$ \\
\hline$\%$ of assets controlled by women & $\mathrm{x}$ & $\mathrm{x}$ & & & \\
\hline $\begin{array}{l}\text { \% of spending controlled by } \\
\text { women }\end{array}$ & $\mathrm{x}$ & $\mathrm{x}$ & & & \\
\hline $\begin{array}{l}\text { Race (four groups, african black is } \\
\text { the base) }\end{array}$ & & & & $\mathrm{x}$ & $\mathrm{x}$ \\
\hline \multicolumn{6}{|l|}{ Dummies } \\
\hline $\begin{array}{l}\text { Water access in/or close to the } \\
\text { house }\end{array}$ & $\mathrm{x}$ & $\mathrm{x}$ & $\mathrm{x}$ & $\mathrm{x}$ & $\mathrm{x}$ \\
\hline Uses wood & $\mathrm{x}$ & $\mathrm{x}$ & $\mathrm{x}$ & $\mathrm{x}$ & $\mathrm{x}$ \\
\hline Uses electricity & $\mathrm{x}$ & $\mathrm{x}$ & $\mathrm{x}$ & $\mathrm{x}$ & $\mathrm{x}$ \\
\hline Lives in urban area & $\mathrm{x}$ & $\mathrm{x}$ & $\mathrm{x}$ & $\mathrm{x}$ & $\mathrm{x}$ \\
\hline $\begin{array}{l}\text { Lives in a house that is a separate } \\
\text { unit }\end{array}$ & & $\mathrm{x}$ & & $\mathrm{x}$ & $\mathrm{x}$ \\
\hline $\begin{array}{l}\text { Lives close to public } \\
\text { transportation }\end{array}$ & & & $\mathrm{x}$ & & \\
\hline $\begin{array}{l}\text { Consumption group (four groups, } \\
\text { lowest is the base) }\end{array}$ & $\mathrm{x}$ & $\mathrm{x}$ & $\mathrm{x}$ & $\mathrm{x}$ & $\mathrm{x}$ \\
\hline Is Christian & $\mathrm{x}$ & $\mathrm{x}$ & & & \\
\hline
\end{tabular}




\section{APPENDIX B: SAMPLE}

The time use survey data sample for each of the countries has been restricted according to five criteria. In table B.1 we report the size of the samples according to these restrictions. The first three restriction criteria are households that are headed by a couple, that is not of the same sex, and for which we have information on time use data available for both spouses. The fourth and fifth criteria, for which we report the breakdown below, are that both spouses should be aged between 18 and 75 years old and that the household should not have other adults present.

Table B.1. Sample Sizes by Restrictions

\begin{tabular}{|c|c|c|c|c|c|c|c|c|c|c|}
\hline & \multicolumn{2}{|c|}{$\begin{array}{c}\text { Ethiopia } \\
2013 \\
\end{array}$} & \multicolumn{2}{|c|}{$\begin{array}{c}\text { Ghana } \\
2009 \\
\end{array}$} & \multicolumn{2}{|c|}{$\begin{array}{c}\text { Tanzania } \\
2006 \\
\end{array}$} & \multicolumn{2}{|c|}{$\begin{array}{c}\text { South Africa } \\
2000\end{array}$} & \multicolumn{2}{|c|}{$\begin{array}{c}\text { South Africa } \\
2010 \\
\end{array}$} \\
\hline & Number & Percent & Number & Percent & Number & Percent & Number & Percent & Number & Percent \\
\hline $\begin{array}{l}\text { Couple headed where both } \\
\text { spouses have time use data }\end{array}$ & 12,313 & 100 & 1,467 & 100 & 1,858 & 100 & 1,496 & 100 & 3,048 & 100 \\
\hline Omitted because of age & 480 & 4 & 44 & 3 & 71 & 4 & 60 & 4 & 120 & 4 \\
\hline $\begin{array}{l}\text { Omitted because of } \\
\text { extended adult members }\end{array}$ & 2,726 & 22 & 400 & 27 & 518 & 28 & 147 & 10 & 381 & 13 \\
\hline Both of the above & 143 & 1 & 14 & 1 & 34 & 2 & 6 & 0 & 20 & 1 \\
\hline Final sample & 9,250 & 75 & 1,037 & 71 & 1,303 & 70 & 1,295 & 87 & 2,567 & 84 \\
\hline \% Loss & 25 & & 29 & & 3 & & 13 & & 16 & \\
\hline
\end{tabular}




\section{APPENDIX C. PREDICTED OUTCOMES AND MARGINAL EFFECTS}

One of the difficulties of using nonlinear models, like the bivariate Tobit presented here, is that its outcomes cannot be interpreted directly, except for some notion of the direction of the effect. However, since the interest often falls in estimating the actual impact of exogenous changes in the independent variables on the outcome of interest, in the context of the present paper, we concentrate the analysis on three specific outcomes, which we define next.

Consider a bivariate normal censored distribution defined by:

$$
\begin{gathered}
h_{h}=\left\{\begin{array}{l}
h_{h}^{*}+\varepsilon_{h} \text { if } h_{h}^{*}+\varepsilon_{h}>0 \\
0 \text { otherwise }
\end{array}\right. \\
h_{w}=\left\{\begin{array}{l}
h_{w}^{*}+\varepsilon_{w} \text { if } h_{w}^{*}+\varepsilon_{w}>0 \\
0 \text { otherwise }
\end{array}\right. \\
\varepsilon_{h}, \varepsilon_{w} \sim N\left(\begin{array}{l}
0 \\
0
\end{array},\left[\begin{array}{cc}
\sigma_{h}^{2} & \rho \sigma_{h} \sigma_{w} \\
\rho \sigma_{h} \sigma_{w} & \sigma_{w}^{2}
\end{array}\right]\right)
\end{gathered}
$$

The expected number of hours in which the husband/wife is predicted to engage, conditional on having any positive hours but unconditional on the spouse' decision, is defined as:

$$
E\left(h_{k} \mid h_{k}>0\right)=h_{k}^{*}+\sigma_{k} \frac{\phi\left(h_{k}^{*} / \sigma_{k}\right)}{\Phi\left(h_{k}^{*} / \sigma_{k}\right)} \text { for } k=h, w
$$

where $\phi($.$) and \Phi($.$) are the pdf and cdf of the standard normal distribution function. The$ probability that the husband/wife engages in any positive number of hours of household production, unconditional on spouse's decision is given by:

$$
\operatorname{Pr}\left(h_{k}>0\right)=\Phi\left(h_{k}^{*} / \sigma_{k}\right) \text { for } k=h, w
$$

The unconditional expected number of hours of household production that a husband/wife would engage in unconditional on spouse's decisions is: 


$$
\begin{gathered}
E\left(h_{k}\right)=E\left(h_{k} \mid h_{k}>0\right) \operatorname{Pr}\left(h_{k}>0\right) \\
E\left(h_{k}\right)=h_{k}^{*} \Phi\left(h_{k}^{*} / \sigma_{k}\right)+\sigma_{k} \phi\left(h_{k}^{*} / \sigma_{k}\right) \text { for } k=h, w
\end{gathered}
$$

Finally, given the main interest of the paper is to analyze factors that influence the allocation of time between husband and wife, we also define the unconditional expected share of hours that a husband/wife will engage in as a percentage of expected total hours of work:

$$
E\left(S h_{h}\right)=\frac{E\left(h_{h}\right)}{E\left(h_{h}\right)+E\left(h_{w}\right)} * 100
$$




\section{APPENDIX D: WEALTH INDEX}

The wealth index was estimated at the household level using principal component analysis. The variables selected for the estimation followed a general rule but varied according to data availability per country. Ownership of appliances, source of energy and water, proximity to schools, hospital, and public transportation, and materials used in the construction of the housing unit were all included when available.

Principal component analysis allows us to maximize the amount of variance in the data that is explained while reducing its dimension. We ran two separate estimations, one for urban households and one for rural households, and used each of them to calculate the index according to the household's location. The results are presented in table D1. Except for Ghana, the explanation power of the indices is higher in urban areas.

Table D.1. Principal Component Analysis, Selected Results

$\begin{array}{ccccc}\text { Ethiopia } & \text { Ghana } & \text { Tanzania } & \text { South Africa } & \text { South Africa } \\ 2013 & 2009 & 2006 & 2000 & 2010\end{array}$

$\%$ of variance explained by the first component:

\begin{tabular}{lrrrrr} 
Urban area & 18 & 13 & 18 & 32 & 27 \\
Rural area & 8 & 16 & 14 & 25 & 24 \\
\hline \hline
\end{tabular}

First component eigenvalue:

\begin{tabular}{llllll} 
Urban area & 2.83 & 8.22 & 4.36 & 5.02 & 6.05 \\
\hline Rural area & 6.21 & 6.93 & 5.86 & 6.31 & 6.37 \\
\hline
\end{tabular}




\section{APPENDIX E: WATER, WOOD, AND ELECTRICITY IN URBAN AND RURAL}

AREAS

In rural sub-Saharan Africa, the necessity of fetching wood and water is a reality for many households; furthermore, they are mostly the responsibility of women, as table E.1 shows. The time spent on these activities has been added to household production, therefore we should aspect that the need to gather water and wood, which is dependent on a household's water and energy sources, would increase the total hours of household production. Nonetheless, there is a high correlation between the source of energy and proximity to water, and the location of household's residence (rural or urban). The breakdown of the percentage of households that use wood, electricity, and that have close access to water by urban and rural locations are presented in table E.1

Table E1. Percentage of Households with Selected Characteristics Regarding Energy and Proximity to Water Sources (percent)

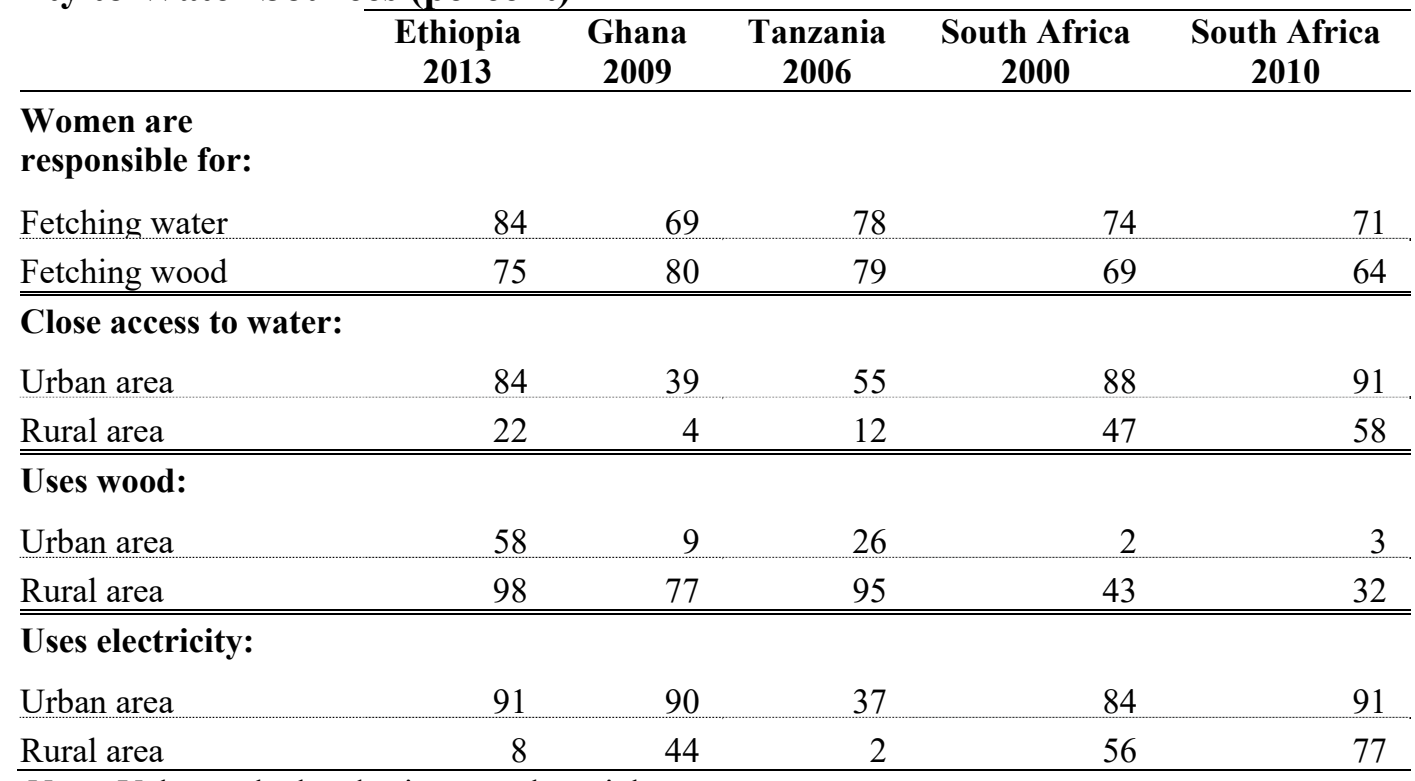

Note: Values calculated using sample weights. 


\section{APPENDIX E: EDUCATION RECLASSIFICATION}

Because different education systems exist across countries, data were recoded to obtain a measure that is comparable across countries. Table F.1 summarizes the reclassification used for this research.

Table F.1. Reclassification of Education Variables by Country

\begin{tabular}{|c|c|c|c|c|c|}
\hline & $\begin{array}{c}(1) \\
\text { Ethiopia } \\
2013\end{array}$ & $\begin{array}{c}\text { (2) } \\
\text { Ghana } \\
2009 \\
\end{array}$ & $\begin{array}{c}(3) \\
\text { Tanzania } \\
2006\end{array}$ & $\begin{array}{c}(4) \\
\text { South Africa } \\
2000\end{array}$ & $\begin{array}{c}(5) \\
\text { South Africa } \\
2010\end{array}$ \\
\hline & $\begin{array}{c}\text { Highest grade } \\
\text { completed }\end{array}$ & $\begin{array}{c}\text { Highest level } \\
\text { of school }\end{array}$ & $\begin{array}{c}\text { Education } \\
\text { level }\end{array}$ & $\begin{array}{c}\text { Highest grade } \\
\text { passed }\end{array}$ & $\begin{array}{c}\text { Highest } \\
\text { education level }\end{array}$ \\
\hline $\begin{array}{l}\text { Preschool } \\
\text { or no } \\
\text { education }\end{array}$ & "preschool" & $\begin{array}{l}\text { "preschool" } \\
\text { and "don't } \\
\text { know" }\end{array}$ & $\begin{array}{l}\text { "never } \\
\text { attended" }\end{array}$ & grades 0 and 1 & $\begin{array}{l}\text { "no schooling" } \\
\text { and "grade } \\
\text { R/0" }\end{array}$ \\
\hline $\begin{array}{l}\text { Primary } \\
\text { education }\end{array}$ & $\begin{array}{l}\text { "grade 1" through } \\
\text { "grade 8, and "literacy } \\
\text { campaign," "adult } \\
\text { education," alternative } \\
\text { education" and "non- } \\
\text { formal" }\end{array}$ & $\begin{array}{l}\text { "primary" and } \\
\text { "middle/JSS/ } \\
\text { JHS" }\end{array}$ & $\begin{array}{l}\text { "primary not } \\
\text { complete" }\end{array}$ & grade 2 through 8 & $\begin{array}{l}\text { "grade 1/sub A" } \\
\text { through } \\
\text { "grade } \\
\text { 7/standard 5" }\end{array}$ \\
\hline $\begin{array}{l}\text { Secondary } \\
\text { education }\end{array}$ & $\begin{array}{l}\text { "grade } 9 \text { old curriculum" } \\
\text { through "grade } 12 \text { old } \\
\text { curriculum" and } \\
\text { "completed grade } 9 \\
\text { (current curriculum)" } \\
\text { through "completed } \\
\text { preparatory grade } 12 \text { in } \\
\text { the current curriculum" }\end{array}$ & $\begin{array}{l}\text { "Secondary/ } \\
\text { SSS/SHS" }\end{array}$ & $\begin{array}{l}\text { "primary } \\
\text { complete" }\end{array}$ & $\begin{array}{l}\text { grades } 9 \text { through } \\
11\end{array}$ & $\begin{array}{l}\text { "grade } \\
8 / \text { standard } \\
6 / \text { form 1" } \\
\text { through } \\
\text { "grade 11" }\end{array}$ \\
\hline $\begin{array}{l}\text { Tertiary } \\
\text { education }\end{array}$ & $\begin{array}{l}\text { "10+1/in the new } \\
\text { vocational" through } \\
\text { "above degree (level 4) } \\
\text { completed new } \\
\text { curriculum" and } \\
\text { certificates, diplomas, } \\
\text { and degrees }\end{array}$ & $\begin{array}{l}\text { "training } \\
\text { college," } \\
\text { "polytechnic" } \\
\text { and } \\
\text { "university" }\end{array}$ & $\begin{array}{l}\text { "secondary } \\
\text { above" }\end{array}$ & grade 12 & $\begin{array}{l}\text { "grade } \\
12 / \text { standard } \\
10 / \text { form } \\
5 / \text { matric" } \\
\text { through } \\
\text { "bachelors } \\
\text { degree and } \\
\text { diploma" }\end{array}$ \\
\hline
\end{tabular}

